IZA DP No. 8998

Market Distortions and Political Rent: The Case of Fertilizer Price Divergence in Africa

Abebe Shimeles

Daniel Zerfu Gurara

Dawit Birhanu Tessema

April 2015 


\title{
Market Distortions and Political Rent: The Case of Fertilizer Price Divergence in Africa
}

\author{
Abebe Shimeles \\ African Development Bank \\ and IZA \\ Daniel Zerfu Gurara \\ African Development Bank \\ Dawit Birhanu Tessema \\ African Development Bank
}

Discussion Paper No. 8998

April 2015

IZA

P.O. Box 7240

53072 Bonn

Germany

Phone: +49-228-3894-0

Fax: +49-228-3894-180

E-mail: iza@iza.org

\begin{abstract}
Any opinions expressed here are those of the author(s) and not those of IZA. Research published in this series may include views on policy, but the institute itself takes no institutional policy positions. The IZA research network is committed to the IZA Guiding Principles of Research Integrity.

The Institute for the Study of Labor (IZA) in Bonn is a local and virtual international research center and a place of communication between science, politics and business. IZA is an independent nonprofit organization supported by Deutsche Post Foundation. The center is associated with the University of Bonn and offers a stimulating research environment through its international network, workshops and conferences, data service, project support, research visits and doctoral program. IZA engages in (i) original and internationally competitive research in all fields of labor economics, (ii) development of policy concepts, and (iii) dissemination of research results and concepts to the interested public.
\end{abstract}

IZA Discussion Papers often represent preliminary work and are circulated to encourage discussion. Citation of such a paper should account for its provisional character. A revised version may be available directly from the author. 


\title{
ABSTRACT \\ Market Distortions and Political Rent: The Case of Fertilizer Price Divergence in Africa*
}

\begin{abstract}
We examine the fertilizer retail-import price gap in 14 African countries between 2002 and 2013. This price differential is large and remains persistent even after accounting for changes in the cost of domestic transportation. We hypothesize that these persistent deviations may be indicative of market power by importers/suppliers granted to them by governments that are prepared to bar competition in exchange for political rent. Our results show that the retailimport price differential is negatively correlated with government effectiveness. Quality of institutions both in terms of executing public policy and delivering services is, on average, likely to affect retail-import price gaps. Overall, our understanding of market imperfections is enhanced by a closer examination of the role of governance and regulation. The study illustrates this by establishing a link between retail-import price differentials and market efficiency and the quality of regulatory environment in Africa.
\end{abstract}

JEL Classification: D43, O12

Keywords: market distortions, political rent

Corresponding author:

Abebe Shimeles

African Development Bank Group

Immeuble du CCIA

Avenue Jean-Paul II

01 BP 1387 Abidjan 01

Côte d'Ivoire

E-mail: a.shimeles@afdb.org

\footnotetext{
* An earlier version of this paper was presented at the Columbia-Cornell-DFID-World Bank Conference on Markets, Labour and Regulation held in New Delhi, December 17-18, 2014. We thank participants of this conference for valuable comments. All remaining errors are ours. The opinion expressed in this paper are that of the authors and do not represent that of the African Development Bank Group, the Board of Directors and the countries they represent.
} 


\section{Introduction}

On the average, external trade accounts close to one-third of GDP in Africa and has been rising over time (UNCTAD, 2013). In some countries this ratio is substantially large, exceeding 85 percent ${ }^{1}$. Its contribution to government revenue as well is very significant. In the political climate that prevails in most parts of Africa, control of the structure of the external trade sector is a convenient source of rents to political loyalists. The recently documented illicit financial outflows are testament to this assertion (GFI, 2013)2 ${ }^{2}$. The study contributes to this evolving literature by linking persistent price distortions to entrenched market power and uses market imperfection in the African fertilizer market to illustrate this point. There are several advantages to looking at fertilizer price distortions. First, fertilizer is a globally traded homogenous product. Therefore, its price structure is not affected by brands, quality, and other forms of product differentiation that impede contemporaneous and temporal comparisons. Secondly, improvements in African agriculture, in particular, and growth of GDP depend on the availability of fertilizer at competitive and affordable prices. Thus, prevailing market distortions could derail the objective of encouraging fertilizer application to transform rural lives.

The long-run differential between domestic retail and world fertilizer price is large and has diverged since the late 1980s. At the beginning of the 2000s, the retail price of urea in Cameroon and Cote d'Ivoire widened to about 5 and 9 times the world price from relatively similar initial levels in 1980 . While this price differential is not showing signs of narrowing, countries with comparable levels of development seem to be experiencing convergence of retail prices. Retail prices of urea in Benin, Cameroon and Senegal have converged in 2002 from their respective levels twenty years earlier. Similarly, retail prices in Egypt, Morocco and Kenya are experiencing convergence, although in both cases domestic price levels have diverged from average world prices.

A majority of African countries rely on imports to satisfy domestic demand for fertilizers. These countries face different import prices (at the dock) accounting for differences in freight, insurance costs and volume of imports. In this study we examine factors explaining the retail-import price gap in a group of African countries. This price differential is large and remains persistent even after accounting for changes in the cost of domestic transportation.

These persistent deviations may be indicative of market power by importers/suppliers exploiting oligopolistic powers granted to them by governments that bar competition in exchange for political rent. Indeed if oligopolistic control of import licenses or domestic

1 Angola, Botswana, Congo Rep., Equatorial Guinea, Liberia, Lesotho, Mauritania, Namibia, Swaziland and Tunisia.

2 Africa loses an average of 5.7 percent of GDP due to illicit financial flows. According to the report by the

Global Financial Integrity trade misinvoicing accounts for nearly 80 percent of these outflows. 
distribution channels can be procured in a political market, the incentive of firms to compete in goods markets is impaired. As a result, a small number of firms operating in such markets could enjoy high and persistent mark-ups.

This problem is compounded by preferential credit rates for input supplying incumbents. Fertilizer importers receive subsidized credit in a number of African countries. Finance for importers eligible for credit is channelled through some government body or agricultural fund. By contrast, start-up firms contemplating entry into the capital intensive business of agro-dealership and distribution borrow at much higher commercial rates. In Senegal, for instance, the Senegalese National Bank for Agricultural Credit provides finance for importers at a subsidized rate of 12 percent visà-vis a commercial market rate of 16 percent for firms setting up new businesses.

In this study, one principal hypothesis is tested. After accounting for differences in transportation cost and other macroeconomic variables, poor quality government bureaucracy leads to a divergence between retail and import prices of fertilizers. Where government bureaucracy is inefficient or the rule of law does not shape behaviour, governments can award import rights in less competitive terms thereby creating and nurturing rents. This often leads to divergence between retail and import prices of fertilizers since minimal competition in the sector implies suppliers are able to set higher mark-ups. Likewise, concentrated markets tend to produce firms that collude to obtain special benefits. In some developing countries, policymakers impose pseudo-entry barriers to protect such special interest groups thereby shielding firms from competition.

Our study relates to the existing literature on price divergence and contemporaneous domestic cost pass-through in the context of developed countries. These include, Gopinath et. al. (2011) and Frankel, Parsley and Wei (2012) which examined exchange rate pass-through to domestic prices using several consumption goods. The interest in these studies is the pass-through of trade costs onto domestic prices. It also relates, to some extent, to works on market concentration and pricing behaviour. There are few studies that focused on developing countries.

Hernandez and Torero (2013) (H-T), appears to be the only recent published work which is an exception. We extend the existing literature in two dimensions. H-T showed the close relationship between high retail fertilizer prices in developing countries and the concentration of productive capacity elsewhere. H-T apply dynamic panel methods to annual urea price in 38 countries over the period 1970-2002. They provide evidence in support of the argument that urea prices tend to be higher in countries that import from less competitive markets where productive capacity is concentrated and a small number of firms exercise market power. H-T estimated around 13-19 percent increase in fertilizer 
use as a result of a $10 \%$ increase in competition in the sector. Equivalently, rural incomes in sub Saharan Africa rise 1-2\% as a result of competition in global fertilizer market.

Unlike Hernandez and Torero (2013) we examined the role of institutional barriers to competition in the domestic market and its role in creating price divergence. Also, closer observation of price data shows a wider retail-import price differential than importworld price differential. Since a majority of the fertilizer consumed in the sampled countries is imported, it implies price distortions may be better explained by market concentration of importers in these countries rather than the concentration of producers elsewhere. This has significant policy implications.

To explore these issues, we constructed a unique panel dataset for fourteen African countries containing, among other, fertilizer import and retail price, inland transportation cost, taxes and tariff on fertilizer, and a range of indicators of market efficiency.

\section{Background on the African Fertilizer Market}

\section{Small market size and urea import price convergence:}

In Africa, fertilizer production capacity is limited and concentrated in a few countries. The average ratio of fertilizer production per annual consumption, between 2010 and 2012 , stood at $0.9 \%$. The same ratio over the past decade was $0.6 \%^{3}$. A bulk of annual domestic use, therefore, relies on imports, and re-exports to landlocked countries within the region 4 . Imports are mainly handled by the private sector, although governments play a major role in some countries by directly participating in imports or utilizing the services of private sector importers for their fertilizer subsidy programs. Therefore the supply chain begins with imports followed by distribution which involves inland transportation from ports to agro-dealers and distributors. At the end of the supply chain, distributors and agro-dealers are involved in fertilizer blending and providing it to end users.

The fertilizer market in Africa is very small compared to the rest of the developing world due to supply and demand side constraints (including small market size, lack of competition among suppliers, and cost of finance) (see Morris et al. 2007, and Hernandez and Torero, 2013). The supply/demand constraints are exacerbated by a host of transaction costs hindering the effective participation of the private sector (weak

\footnotetext{
${ }^{3}$ International Fertilizer Development Center (2013)
}

${ }^{4}$ Hernandez and Torero (2013) 
fertilizer marketing and distribution systems, and poor infrastructure). As a result, irregular, costly supply and low demand continue to epitomize Africa's fertilizer sector.

\section{The Political Economy of Fertilizer Market}

Government behaviour is determined by economic, political and institutional factors. In the absence of a strong system of checks and balances, it is easier for governments to redistribute resources towards special interests.

Recent reviews of fertilizer markets in Nigeria and Senegal reveal such patterns. In both countries domestic prices are determined on a tender based process in which the respective governments negotiate with importers to supply to all states/districts. In both countries, the retail prices largely reflect the price negotiated by suppliers and the government. Evidently government tender in both countries tend to be non-transparent and dominated by a limited number of private sector input suppliers. In the case of Nigeria, three suppliers with close ties to the government dominate the market. Similarly, in Senegal, five private companies with close relations to the Ministry of Agriculture control a significant proportion of fertilizer supply. The absence of competition in these markets has sustained distribution and marketing margins in excess of 22-25 percent in both countries.

Figure 1 illustrates the effect of regulatory quality on retail-import price deviations (Gap). It shows that delays in time to import as a result of regulatory burden correlates with retail-import price differentials. Countries whose regulatory environment is conducive to business operation tend to have lower 'Gaps' than countries at the opposite end. These regulatory barriers could limit competition in the fertilizer market and lead to large deviations between import and retail prices.

\footnotetext{
${ }^{5}$ IFDC-IFPRI (20II)
} 


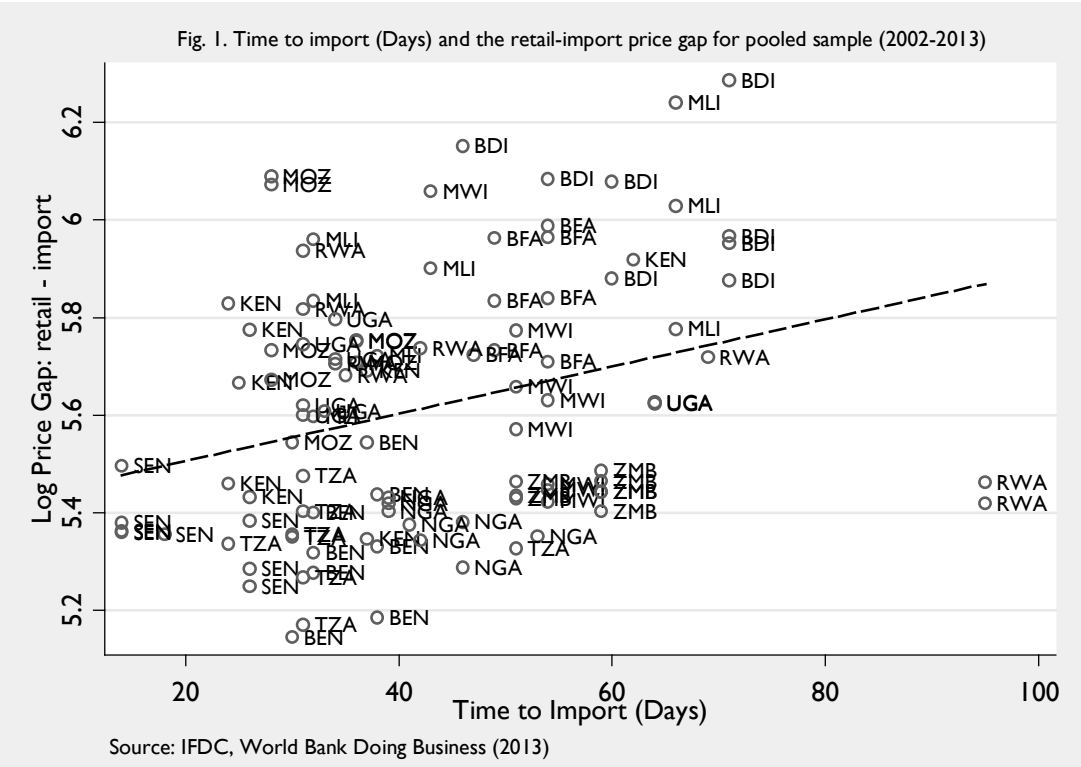

\section{Retail fertilizer price convergence}

Retail price dynamics in Africa is neither well understood, nor often investigated. This is mainly because of the paucity of data on the structure of fertilizer markets, inland transportation costs, and the organization of dealer/supplier networks. Insightful regional level analyses are sparse and, if available, deal with case studies based on country specific surveys of domestic fertilizer distribution, conduct and performance.

Regardless of the paucity of data, some critical relationships can be established using cross-country comparable panel data on retail prices, the size of fertilizer markets, and the cost of finance.

For instance it is widely known that small market size limits competition among suppliers. In countries with large markets, domestic input prices tend to fall as competition among input suppliers and agro-dealers shaves-off costs and profit margins. This effect is captured in the following series of plots that look at retail urea prices in 19 African countries ${ }^{6}$. As shown in the plots, retail prices are lower in countries where the demand for fertilizer is relatively large in terms of total fertilizer use/area harvested.

The relationship depicted in the plots portrays the likelihood that relatively large demand for inputs promotes competition among input suppliers, and reduces the gap

${ }^{6}$ Benin, Burundi, Burkina Faso, Cameroon, Cote d'Ivoire, Egypt, Ethiopia, Guinea, Kenya, Malawi, Mali, Mauritania, Morocco, Niger, Nigeria, Senegal, South Africa, Swaziland, and Togo. 
between import prices and retail price of inputs. On average, countries with larger fertilizer consumption per area harvested faced lower retail prices and lower gap between retail and import prices.

Fig. 1. Retail urea prices and fertilizer demand in selected African countries
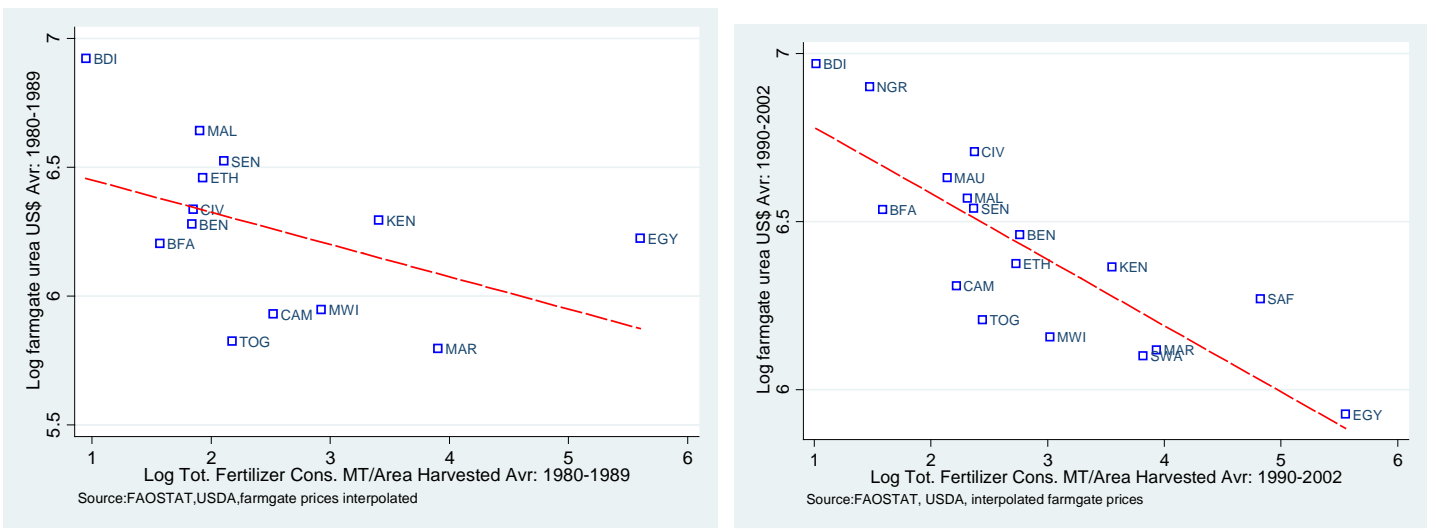

Countries with small fertilizer use per area harvested have larger urea retail price, even if total urea import is comparatively larger. For instance, between 1990 and 2002, average urea import in Nigeria was 13 times its level in Senegal. Nigeria imported over 64,000 MT of urea and paid an average import price of US\$285/MT compared to Senegal's 4760MT of imports and US\$193/MT in import price. But, average fertilizer consumption per area harvested is larger in Senegal 11MT/1000ha compared to only 4.4 MT/1000ha in Nigeria. As a result, over the period, the retail price of urea in Senegal averaged at US\$693/MT compared to US\$1227/MT in Nigeria.

\section{Transaction Costs and Fertilizer Price}

\section{Transportation costs}

Large freight and inland transportation costs to/in less developed countries can lead to persistently wide gaps between domestic and international prices for homogenous tradable goods. In many African countries the absence of dense rail-networks has resulted in excessive reliance on trucking for transporting cargo over long distances. This often poses a major logistical problem since crowded ports with congested facilities have to open their doors to fertilizer distributors. As a result, offloading cargo from ports to warehouses takes a long time and is costly, especially in countries that have limited port capacity. Also, inland transportation costs tend to be high due to rough terrain and poor road conditions, and limited number of freight market operators. Landlocked countries often incur additional transportation costs which are reflected in retail prices. 
Table 1. Average retail urea prices in \$/MT (1990-2002)

\begin{tabular}{|c|c|c|c|c|c|}
\hline Coastal Countries & $\begin{array}{c}\text { No. of } \\
\text { countries }\end{array}$ & Mean & Std. Dev. & Min & Max \\
\hline Cameroon, Egypt, Senegal, & 11 & 631.24 & 138.12 & 138.12 & 831.62 \\
\hline Landlocked countries & $\begin{array}{c}\text { No. of } \\
\text { countries }\end{array}$ & Mean & Std. Dev. & Min & $\operatorname{Max}$ \\
\hline $\begin{array}{l}\text { Swaziland, Niger, Mali, Burundi, } \\
\text { Malawi, Ethiopia, Burkina Faso, }\end{array}$ & 7 & 680.09 & 194.43 & 501.44 & 1076.59 \\
\hline
\end{tabular}

Urea retail price is larger in landlocked countries than in coastal countries that have their own port facilities. Over the period 1990-2002, average urea retail price in landlocked countries was 50\$/MT higher than the average for the 11 coastal countries. Nevertheless, the poor state of road network and absence of competition in the freight haulage market imply large inland transportation costs pass-through to retail prices, irrespective of geographic location.

Table 2. Cost breakdown of urea retail price in three coastal countries in 2007

\begin{tabular}{cccc}
\hline & Thailand & Tanzania & Mali \\
\hline Retail price (\$/MT) & 282 & 419 & 509 \\
Urea price (f.o.b + bagging) (\$/MT) & 228.42 & 272.35 & 249.41 \\
Transport cost (\$/MT) & 31.02 & 92.18 & 162.88 \\
Taxes + Levies & & 2.095 & 30.54 \\
Finance Cost & 8.46 & 16.76 & 20.36 \\
Total Overheads & 5.64 & 8.38 & 5.09 \\
Total Margins & 8.46 & 27.235 & 40.72 \\
\hline
\end{tabular}

Source: IFDC-IFPRI (2012).

In its survey based review of cost build-up on the urea supply chain, a recent study ${ }^{7}$ found significant differences in the share of inland transport costs on urea retail price even in coastal countries. In Thailand, the world price of urea made up close to $81 \%$ of the retail price in 2007, while the same made up only $65 \%$ and $49 \%$ of retail prices in Tanzania and Mali, respectively. Inland transportation costs were only $11 \%$ of retail

7 IFDC-IFPRI (2011) 
prices in Thailand, while the same figure for Tanzania and Mali were $22 \%$ and $32 \%$. In the two coastal African countries, distributor margins are more than twice their level in Thailand.

\section{Cost of Credit}

Banking systems in Africa exhibit: large spreads between deposit and lending rates, large shares of NPLs, and the absence of efficient legal procedures to facilitate speedy recovery of bad loans. Lending rates, therefore, tend to be large for a variety of reasons including the limited number of banking institutions and the absence of competition. Risk premia on domestic lending measured as the difference between bank lending rates and the risk free rate are not significantly higher in Africa than other developing regions.

Access to credit markets is essential to ensure smooth operations in input markets. Timely access to credit by input supplying incumbents stabilizes prices during times of high demand for inputs. Similarly, if potential entrants attracted by wide profit margins have comparable access to credit, competition among suppliers drives down profit margins and prices.

However, these forces of competition are largely absent from African input markets partly due to high borrowing costs caused by credit rationing. Governments implement financially repressive policies to control fiscal resources ${ }^{8}$. Direct control over the financial system provides governments with access to cheap credit than if they had to rely on market financing. Such credit rationing crowds out private investment, raises interest rates the cost of setting up businesses, and limits the number of firms participating in markets (including input markets).

\section{Data}

We focus on a panel of 14 African countries ${ }^{9}$ over a 12 year period (2002-2013). We were able to find a relatively complete set of price data for this group of countries. The retail urea price series were pieced together from three sources: FAO Stats, IFDC Fertilizer assessment reports, and East African Agricultural Input Market Information and Transparency System (AMITSA) ${ }^{10}$. Each price data-point is treated as the annual average for each respective country. IFDC surveys were conducted during the onset of the rainy season and represent the upper margin of annual prices. Local retailers rarely hold off-season stocks since maintaining a depot entails sizable fixed costs. Retail price series from all

\footnotetext{
8 High liquidity ratio, high reserve requirements and interest ceilings.

9 Benin, Burkina Faso, Burundi, Ethiopia, Kenya, Malawi, Mali, Mozambique, Nigeria, Rwanda, Senegal, Tanzania, Uganda, and Zambia

${ }^{10}$ An IFDC, EAC, COMESA initiative
} 
sources are converted into a common currency (US\$/ton). Data points that exceed the cross-sectional median by more than a factor of 3 are set to the median value of the remaining series. Missing price series of one year were interpolated using the average of adjacent year values.

We constructed the unit import price series from the International Trade Centre (ITC) database. Also, total value and volume of urea imports for each country were compiled from the same source and cross-checked with UNCOMTRADE data. Alternative estimates of the fertilizer market size in each country were computed as a ratio of total fertilizer consumption (metric tons of $\mathrm{N}, \mathrm{P} 2 \mathrm{O} 5$, and $\mathrm{KO} 2$ ) to total area harvested (temporary and permanent crops). We compiled these figures from http:/ / www.ers.usda.gov/ data-products/international-agricultural-productivity.aspx.

These figures are cross-checked for consistency with fertilizer consumption data from IFDC and AMITSA.

In addition to price data from IFDC, AMITSA and ITC, we rely on World Development Indicators 2014 for GDP deflator and lending rate series. A three year moving average of inflation is constructed using GDP deflator data as an alternative to rolling three year average CPI inflation. CPI inflation, nominal exchange rate, lower bound on tariff rates (MFN tariff rates on chemicals), and nominal effective exchange rates are obtained from UNCTAD statistics. We constructed two and three year rolling average inflation rates and standard deviation of nominal exchange rates against the dollar. We experiment with one or more specifications including a variety of short-term nominal exchange rate and inflation volatility. In all cases, the variants serve as measures of short-term pass through.

Since data on inland transportation cost is hard to come by (especially true for this group of countries), we use 'cost-to-import' from World Bank's Doing Business Surveys as a useful proxy. In its original form 'cost-to-import' measures fees levied on a 20-foot container in U.S. dollars (fees including costs for documents, administrative fees for customs clearance and technical control, customs broker fees, terminal handling charges and inland transport). The measure includes all such official import costs with the exception of taxes and tariffs. We convert the costs incurred as per a standard unit for measuring container capacities -twenty foot equivalent unit (TEU) ${ }^{11}$. The maximum gross mass of a $20 \mathrm{ft}$ dry cargo container is about $24 \mathrm{MT}$. A $20 \mathrm{ft}$ standard container has a tare mass (unladen weight) of roughly 1.8 - 2.4 MT depending on construction. The maximum payload mass of a 20ft container is, therefore, approximately $21.6 \mathrm{MT}$.

11 World Shipping Council 
Also, Doing Business indicators are used to measure the extent to which regulatory environment in each country is conducive to business. We pay particular attention to 'time to import' that estimates time needed to process official documents, inland transport and handling, customs clearance and inspection, port-terminal handling (excluding actual length of sea transport). Time is recorded in calendar days and represents a composite measure of port-service effectiveness and public service administrative efficiency and is comparable across countries. Intuitively, it assumes away possibilities where importers or exporters are responsible for delays. In landlocked economies, the measure also reflects the efficiency of public service delivery in the transit economy.

We use the best available estimates of domestic market size and efficiency from various issues of The Global Competitiveness Report. More specifically we use 'goods market efficiency' and 'domestic market size'. Goods market efficiency is measured as a composite index of domestic competition intensity and extent of market dominance, among others, each measured on a scale 1 to 7 . The lower bound of the scale characterizes low intensity of competition and markets dominated by few business groups, while the upper bound correspond to intense local competition and market dominance spread among many firms.

The size of the domestic market is constructed as the natural log of the sum of GDP (PPP) plus the total value (PPP) estimates of imports of goods and services, minus the total value (PPP estimates) of exports of goods and services. Similarly, the data is normalized on a 1-to-7 scale. Obviously these indicators are aggregate measures of domestic competition and therefore may not clearly capture the extent of market efficiency in specific sectors or among importers of a particular product. But one can make a case for these measures providing an indicative benchmark.

\section{Empirical strategy}

Often import prices are estimated as a ratio of import value to total tonnage. Consequently, there is fear that large price differentials between import-quotes (unit values) and domestic prices of imported products is a statistical artefact. Nevertheless, a small body of anecdotal evidence and case studies of the fertilizer market in Africa confirm genuine differences in price differentials ${ }^{12}$. Price comparisons further indicated that the differential was not purely a function of inland transportation costs.

In developing countries, fertilizer imports are logistically demanding and require substantial investments. Firms with access to domestic and foreign financing and are

12 Morris et. al. (2007), Johnson et. al. (2008) 
able to meet stringent collateral requirements tend to dominate the market. The need to buy large quantities to benefit from economies of scale tends to create oligopolies in small markets often resulting in substantial margins.

Intuitively, reducing some of the barriers to business development should reduce price differentials and make fertilizer products affordable to farmers. The resulting growth in consumption encourages competition among suppliers and keeps price differentials in check.

Consider the following model. Import demand expands in accordance with trend growth of domestic output, where $p_{i, t}^{m}, m_{i, t}$, and $g_{i}$ are, respectively, import price (c.i.f) in country $i$ at time $t$, import demand and long-run growth in agriculture output.

$p_{i, t}^{m} m_{i, t}=B_{i} e^{g_{i} t}$

The domestic price of the imported product in country $i$ at time $t p_{i, t}$ depends on group and time varying characteristics $c_{i, t}$ (capital costs incurred by importers, inland transportation and administrative costs), rolling average of inflation rate $\pi_{i, t}$, volatility of the exchange rate $\sigma_{i, t}$ and time invariant country characteristics $A_{i}$.

$p_{i, t}=A_{i} p_{i, t}^{m} c_{i, t} e^{\left(\pi_{i, t}+\sigma_{i, t}\right) t}$

The contemporaneous price gap is therefore defined as $\mathrm{Y}_{i, t}=p_{i, t}-p_{i, t}^{m}$, and its natural $\log$ form can be approximated by (4)

$\mathrm{Y}_{i, t} \cong B_{i} A_{i} c_{i, t} m_{i, t}^{-1} e^{\left(g_{i}+\pi_{i, t}+\sigma_{i, t}\right) t}$

$\ln Y_{i, t}=\delta+\mu_{i}+\theta_{1} \ln c_{i, t}+\theta_{2} \ln m_{i, t}+\theta_{2}\left(\pi_{i, t} \times t\right)+\theta_{2}\left(\sigma_{i, t} \times t\right)+\varepsilon_{i, t}$

We begin with a very simple benchmark model where the contemporaneous price gap is a function of inland transportation and administrative costs, inflation, exchange rate volatility and country dummies. Next, we sequentially add variables to the $C$ matrix beginning with log consumption of the fertilizer product. Finally, we include interaction terms of inflation and exchange rate against time trends to capture the degree of passthrough.

The variables included in the core model (equation 4) are defined as:

$\ln Y_{i, t}=\log$ price gap (contemporaneous)

$\ln (T P)=\log$ inland transportation and administrative costs

$r_{i, t}=$ nominal cost of capital (lending rate) 
$\ln \left(\right.$ cons $\left._{i, t}\right)=\log$ consumption of urea (tons)

$\pi_{i, t} \times t=$ interaction term between three year average of inflation and trend

$\sigma_{i, t} \times t=$ interaction $b / n$ two year standard deviation of LCU/US\$ and trend

Various forms of equation 4 were estimated. We report a slightly different variation of equation 4 . But the essence of the relationships that we are trying to capture is unchanged.

Next, we look at the relationship between the combined residual from equation 4 and measures of market efficiency and bureaucratic quality $\Psi_{i, t}$.

$\mu_{i}+\varepsilon_{i, t}=\phi+\sum_{i} \alpha_{i} \Psi_{i, t}+\xi_{i, t}$

\section{Descriptive statistics -market segmentation}

The figures below summarize the behaviour of the price-gap, import and local prices in two groups of countries over two periods: between 2002 and 2005, and after 2005 for the full data. Again, the price-gap is the simple difference between local retail and import prices (expressed in logs. First, we observe that the spread and mean of the price-gap remains relatively unchanged during the two epochs. Overall the standard deviation of the price-gap (log) diverged from the full sample mean by only 0.5 percent, and 3 percent over the two periods.

Fig 2.1a. The persistence of urea retail-import price differential

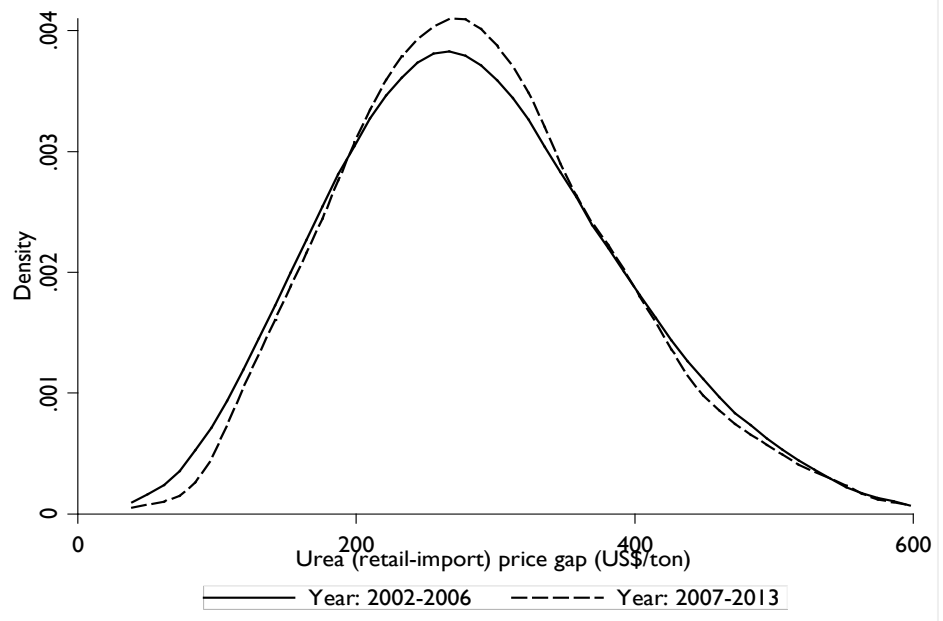

Secondly, domestic prices tend to be stickier than import prices. In East Africa, average retail urea price tracked an equivalent increase in import prices. In West Africa retail prices remained stagnant in the face of rising import prices. Over the two periods, the mean of urea import price increased in the sampled East African countries, while its 
dispersion declined. Average import price rose by about 6.7 percent in periods 2 (20062013) while the same for retail prices was about 3 percent. By contrast, import and retail prices in West Africa, increased by about 8.7 percent and 1 percent shaving off about 6 percent from the retail-import price gap.

Fig 2.1b. The persistence of urea retail-import price differential -West Africa

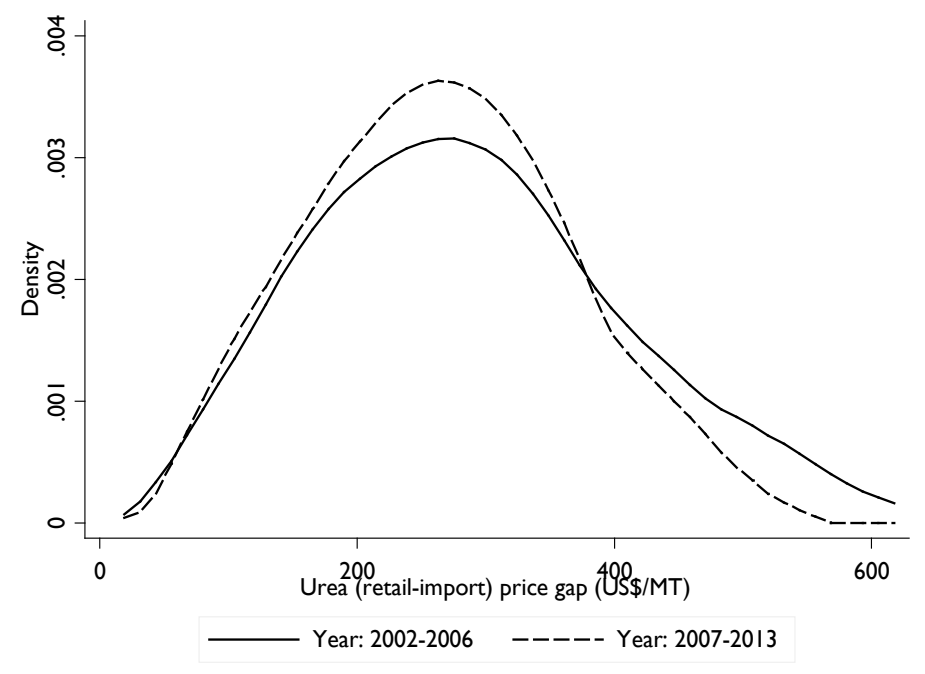

Fig 2.1c. The persistence of urea retail-import price differential-East Africa

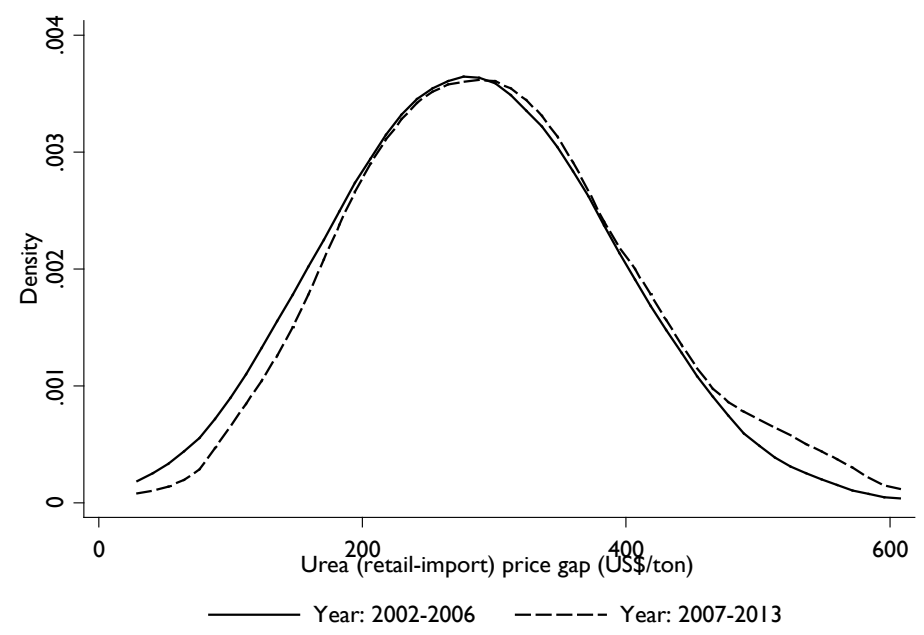

In an integrated regional market one expects to see declining price-gaps over time. When arbitrage opportunities present themselves they are fully exploited. Twelve years is, thus, too long for price divergence to persist in integrated markets. When markets are segmented, the decline of retail-import price-gaps over time hinges on how quickly local costs are reduced (e.g. inland transportation and administrative costs, and barriers to 
competition). It is, therefore, intuitive to suspect that the persistent price gaps are either due to structural impediments to the efficient functioning of the markets in these countries (bureaucratic inefficiency), or due to large local costs to businesses (lack of access to ports or high transportation costs) even after accounting for income differences in these countries.

\section{Results}

\section{Determinants of price differential}

Table 4 presents the coefficient estimates of the price-differential equation (eq. 4). We report cluster robust standard errors. We include year and country dummy variables to take care of time or group specific omitted variables. A fixed effects estimation of equation 4 is believed to capture at least some of the differences in price-differentials despite throwing out a great deal of variation in the data.

In column 1, the specification includes transport and administrative costs and interest rate only. The prime rate is marginally significant at conventional bounds. According to these estimates, a 5 percentage point decline in the prime rate reduces the price-gap by about US\$7 (2005 US\$), on average, or about 2.5 percent. These results are not surprising. While access to credit is essential to smooth operations in input markets, it is largely missing or is priced to the disadvantage of the private sector. As a result the pass-through of cost of credit is reasonably persistent.

Also, we suspect that a fair amount of inland transport and administrative costs ${ }^{13}$ passthrough to domestic prices -especially in the sampled group. Intuitively, we expect to find the impact of this variable to be positive and strongly significant. The coefficient on inland transport and administrative costs is, however, statistically insignificant possibly due to the omission of important time-varying variables (for instance income). This result does not persist in subsequent specifications.

In columns 2-4, log per-capita income is used to instrument for inland transport cost. High income countries tend to have better infrastructure that often reduces the cost of transportation. After controlling for income, the coefficient on inland transport and administrative costs is significant. The results indicate that the cost of inland transportation and government bureaucratic inefficiency pass-through to domestic prices. Even though we are not entirely confident that income solely accounts for the variation in infrastructure quality across countries, it is a good predictor. If that is a

${ }^{13}$ Including import document processing costs, administrative fees for customs clearance and technical control, customs broker fees, terminal handling charges 
reasonable assumption, then, at least two-thirds of the effect of the variable TP on the price-gap (in columns 2-4) is due to transport costs from ports to the major city and the state of competition in the transport sector. The remaining third is due to bureaucratic inefficiency related to import.

In column 3, the specification is extended to include exchange rate volatility (measured as two year rolling standard deviation of LCU/US\$) and an interaction between interest rate and inflation (measured as three year rolling average of change in the GDP deflator). According to the estimates, the impact of inland transportation is significant and has an estimated elasticity of around 0.28 . This implies, on average, a US $\$ 10 /$ ton decline in inland transportation and administrative costs roughly translates into a US $\$ 6.3 /$ ton decline in the average price gap. In a hypothetical (but less likely) scenario where the cost of inland transportation is nil, the average gap could fall by US $\$ 79.28$ $\left(0.627^{*} 126.42\right)$ (a decline of more than one quarter). These estimates confirm the significance of inland transportation costs along the domestic supply chain.

The coefficient on the interaction between lending rate and two-year rolling average inflation is highly significant and largely remains unchanged in the alternative specification. This implies that a reduction in interest rates is likely to reduce the price gap in high inflation times than during lower ones. In liberalized markets, when short term interest rates go down, it becomes cheaper for firms to borrow and expand their input supply business. At the same time, with relatively low barriers to entry, newer firm also find it less costly to join the input supply business. This could spur some competition in the input supply industry and lower mark-ups and, consequently, reduce retail-import price differentials. In a high inflation environment, these effects are magnified. In the sampled countries where nominal interest rates have been historically high, inflation has remained relatively subdued. Even so an increase in medium-term inflation is likely to be transmitted to prices if it is misinterpreted as an increase in longterm inflation.

The coefficient on medium-term exchange rate volatility is statistically insignificant in columns 3 and 4 . This result may seem unintuitive, especially in the light of recent theoretical and empirical findings. One notable study by Frankel et al., 2012 suggest strong transmission of currency movements onto domestic prices, especially in developing countries. Adverse currency movements could lead to import prices that markedly diverge from procurement plans. Importing firms, therefore factor these costs into retail prices. The absence of this effect is particularly puzzling since average import time in our sample is long (42 days) and has a large spread. Nevertheless, exchange rate volatility (measured as two year rolling standard deviations) was fairly small in the sampled countries during the study period which may have masked this relationship. 
Most of the countries have managed floating exchange rates. Also, procurement contracts could potentially come with price/cost adjustment clauses.

In column 4, we added an interaction term between log consumption of fertilizer products and time trend. In our sample log consumption is a fairly accurate predictor of demand and is highly correlated with consumption-per-area harvested. The coefficient of the interaction term is negative and significant, but the meaning of the sign is subject to different interpretations. Where private sector participation is extensive, large demand for fertilizer products facilitates competition among importers, marketers and distributors and lower mark-ups and price gaps. Alternatively, government input subsidy programs in some high demand countries could place retail prices ceilings or lower them by active (public) control of input distribution while leaving import and procurement to private actors. In our sample, countries that instituted subsidy programs, on average, have one and a half times larger irrigated areas (147 in ‘000 ha) and two times larger fertilizer consumption-per-area harvested $(20.2 \mathrm{~kg} / \mathrm{ha})$.

For robustness, Table 5 reports the same regressions, but without the country dummies. Again, most of the results are qualitatively similar.

\section{Regulatory burden and Market Efficiency}

Although some governments demonstrate concern for aggregate welfare, policymaking institutions in others, often, exhibit powers to confine the limits of market efficiency in favour of interest groups. In the absence of checks and balances on government behaviour, the temptation to curb market efficiency is greater. This is no less evident in trade policy where governments are known to exercise leverage to favour some private actors over others. This is amply demonstrated in theoretical and empirical work going back to Baldwin (1985), McGillivray (1997), and Baldwin and Magee (2002).

In the light of substantial developing country dependence on imported products and, ever more so, on inputs, examining the relationship between retail-import price differential in the fertilizer market and governance and market efficiency is crucial.

Nearly all of the countries in our sample import all of the fertilizer consumed in their respective countries. Most of the countries have attempted some form of liberalization, deregulation and privatization over the past three decades. But, governments have often found it imperative to intervene in fertilizer markets either through direct imports or through subsidies (targeted or otherwise). As a result the organization of markets and their conduct in these countries differs greatly. 
But in almost all cases the number of firms at the importer level is small. Given the nature of the fertilizer business (logistical barriers to entry, start-up capital requirements), the formation of oligopolies may not be unnatural, at least in most cases $^{14}$. Most of these firms may not exclusively import fertilizers and have often established close links with offshore suppliers (as in the case of La Cigogne and DTE in Mali - subsidiaries of French firm SIVEX international and a firm based in China). Nevertheless, the extent of competition in the market or its capture is determined by the transparency of market conduct and, therefore, the nature of regulation.

In most of these countries, import has not been entirely deregulated. Rather, a tenderbid system is instituted with effective demand expressed outside the auction system (often by some government ministry). In some of the countries, there are specific requirements for entry into the auction system (particularly, experience in input supply), in others entry into auctions is free and therefore the mix of suppliers awarded import contracts frequently varies. Nevertheless, it is left entirely up to regulators to determine which importers qualify and some of these conducts are known to make market capture an unfortunate possibility especially in economies with minimal checks and balances.

In this section, therefore, we examine the link between retail-import price differentials and measures of bureaucratic quality and market efficiency. Principally, we estimate equation 5

$$
\mu_{i}+\varepsilon_{i, t}=\phi+\sum_{i} \alpha_{i} \Psi_{i, t}+\xi_{i, t}
$$

The left-hand-side is the sum of the factor and error component from the fixed effect regression (equation 4 panel 4 of Table 4). The right-hand-side consists of measures of bureaucratic quality from the World Bank's WGI (2014), market efficiency measures from (GCI), and income per-capita. $\phi$ and $\xi_{i, t}$ are, respectively, the constant and error components.

High income countries are endowed with efficient bureaucracies and markets. Efficient bureaucracies and markets, in turn pave the way for high per-capita income. To take account of these simultaneous effects, each governance and market efficiency indicator is separately regressed on income, and vice-versa. Governance indicators that appear on the right-hand-side are residuals from the regression on income, while goods market

\footnotetext{
14 Between 1992 and 1998 four private input importers in Ethiopia operated side by side with the state owned input marketing agency (AISC). However this short spell of private sector involvement ended in 2002 with shares of private sector import falling to nil from 28 percent in 1996. These companies were unable to compete with regional government owned holding companies that enjoyed larger market shares as a result of peculiarly restrictive public policy. According to one study (Demeke et. al., 1998) farmers whose primary access to fertilizer credits is from government owned banks were not allowed to purchase from private companies.
} 
efficiency is a residual of the regression on income and government effectiveness. Applying this procedure has one drawback. It reduces the sample considerably. Unfortunately, the GCI started publishing its measures of goods market efficiency since 2006. We estimate a simple OLS model with bootstrapped standard errors.

The following set of variables appears in the regressions

$$
\begin{aligned}
& \ln (\mathbb{y})=\log \text { of GDP per-capita (2005 US\$) } \\
& \mathbb{G}=\text { government effectiveness } 15 \\
& \mathbb{M}=\text { goods market efficiency } \\
& \mathbb{S}=\text { fertilizer market subsidy (dummy) }
\end{aligned}
$$

The results are summarized in Table 5. In column 1, we control for GDP per-capita and examine the effect of government effectiveness on remaining variations in the retailimport price gap. The coefficient on government effectiveness is significant and carries the hypothesized sign. Unobserved heterogeneity responsible for retail-import price differential is negatively correlated with government effectiveness. In other words, countries better institutional quality both in terms of executing public policy and delivering services are, on average, likely to have lower retail-import price gaps than those with a persistent history of institutional mismanagement.

As expected, GDP per-capita is highly significant and has a negative coefficient. Its effect does not diminish even after feedback from government and market efficiency is accounted for. In 2013, average per-capita income in the sample was around US $\$ 400$. Even at these levels marginally higher income reduces retail-import price differentials suggesting, perhaps, with higher income countries are able to build productive capacity and, therefore, reduce imports.

In column 2, we added goods market efficiency. The coefficient on the new variable is negative and highly significant. Not surprisingly, economies with relatively robust overall intensity of competition and greater spread of market power end up with lower retail-import price gaps.

We added a subsidy dummy in column 3. The coefficient on the subsidy dummy is negative and statistically significant. Although the effect of a subsidy on retail-import price differential largely hinges on its mode of conduct, the result is not farfetched. For

\footnotetext{
${ }^{15}$ The measure reflects perceptions of the quality of public services, the quality of the civil service and the degree of its independence from political pressures. It also includes the quality of policy formulation and implementation, and the credibility of the government's commitment to such policies. It is measured on a scale of -2.5 (worst) to 2.5 (best).
} 
example, targeted subsidies like the ones practiced in East Africa ${ }^{16}$ (involving voucher systems or other means) are unlikely to influence the differential. By contrast, universal subsidies of the like practiced in most West African counties ${ }^{17}$ are likely to reduce the retail-import price gap since they constitute a form of price control. However, both the average retail-import price differential and actual retail and import prices are marginally smaller in West African subsidy providers than in the East (see fig. 5.) Both virtually import at the same rate, while cost to import and of financing business operations is larger in the East.

Finally, does the relationship between over-regulated markets and price distortions hold for a wider set of goods? We attempt to answer that question next using the prices of a set of consumer goods across a wide group of countries.

\section{Robustness checks}

\section{Data:}

We use pre-processed citywide historical price data from Numbeo-an open, crowd-sourced cost of living database. The price data is collated using multiple user inputs across city/cities within a country in response to a set of questions regarding well-defined consumer items, services and properties. The database is constructed by applying automatic filters to remove outliers from each consumer price report. Subsequently, upper and lower quartiles of price data are removed to generate reasonable mean values. Price data for cities with minimal crowd reports are routinely left out of any computations. Numbeo's historical data has wide country coverage. Also midyear exchange rates are used to convert prices into major currencies.

After accounting for observations dropped for failing the criteria detailed above, the database had in 2010 already compiled price and income data for 61 countries across 119 cities. In 2014, the number of countries and cities covered has grown to 99 and 295, respectively, again with wide variation in number of cities across countries. The US has the highest number of cities covered each year: 24 in 2010 and up to 47 in 2014. The crowd-count is, also, the highest in the US, averaging well over 4000 in the five-years between 2010 and 2014.

We take simple averages of the reported prices (not weighted by city population) to get aggregate figures, by country, for the listed consumer items, and incomes. Whenever there are countries for which reporters are from multiple cities, the prices reflect the average across those cities. For instance, Nigeria is represented by Lagos while Cebu;

${ }^{16}$ Kenya, Malawi, Rwanda, Tanzania, Zambia

${ }_{17}$ Burkina Faso, Senegal, Mali, Nigeria 
Makati and Manila represent the Philippines. The price of consumer items in Nigeria is taken to be the average price reported by 57 people living in Lagos. Similarly, prices in the Philippines are averages for the three cities reported by 233 people over the five-year period. After merging Numbeo's cost of living data with other datasets, we were able to construct an unbalanced panel for 60 countries over 2010-2014 (see appendix, table 6).

We selected four products that can be compared across countries with a reasonable degree of accuracy: a pack of Marlboro cigarettes, Coke/Pepsi $(0.33 \mathrm{ml})$, a pair of Levi's 501 jeans, and a pair of Nike shoes. We assume away any differences in the production locations of these items destined for the respective markets considered. We implicitly take brand identity to imply origin of exports. Respective unit-value data were appended to the series from UN-Comtrade database.

Numbeo's crowd-sourced data has curious features, and much like other self-reported data beg some questions. For instance, since demographic characteristics of the reporters are not included how can one infer the type of the crowd? One approach is to observe self-reported after tax salaries and make comparisons with average income data for the countries using national income accounts data. When such comparisons are made, we observed striking patterns. The earnings data reported by Numbeo, even if based on a handful of cities, is fairly well correlated with per-capita income data for the countries (0.87).

Table 6 summarizes the ratio of per-capita income to reported after-tax salary for each group of countries (defined based on the World Bank's income classification). The average after-tax salary of the 'crowd' in less developed countries is substantially higher than the average income for the respective countries. This is not particularly surprising since metropolitan salaries tend to be much higher than country averages in these countries. For instance the average income of the 66 reporters from Nairobi (Kenya) is ten times higher than the average per-capita income for the country. By contrast, the average annualized incomes of reporters from Ankara, Istanbul and Izmir is on par with average per-capita income in Turkey. The ratio for progressively higher income groups is smaller.

Looking at these differences, one can expect the 'crowd' from less developed countries to fit a certain demographic (people with relatively easy access to the internet, or perhaps expatriates feeling the need to provide organized data for their peers and so on). One would also expect this group to purchase consumer items from higher end stores. If this observation is accurate, then it should, to some extent, serve to equalize the quality of shopping locations across countries. The income distribution in the crowd-sourced data has one added advantage. It over-represents the income group that purchases the selected items -especially in less developed countries. 


\section{Descriptive Statistics:}

Table 7 provides a summary of descriptive statistics by income group. Prices of the selected consumer goods tend to be higher in higher income countries and generally increase with income across time and group.

The five-year moving average of inflation is higher in the low-income group compared to others. Even if historical rates of inflation in these countries may be moderate, it is likely that the average may be picking up recent uptick in inflation in some of the countries. Notably, three of the six countries in our sample (Kenya, Tanzania, and Ethiopia) experienced sharp inflation between 2010 and 2012. Exchange rate volatility was also higher in low-income countries vis-à-vis other groups, for the same reasons.

\section{Results:}

Table 8 summarizes the coefficient estimates of the price equations (a slightly different version of equation 3 is estimated) in levels and in first-difference. Whenever possible the price of domestic substitutes (or a close covariate) is included in the regressions. We include the price of a pair of leather shoes as substitutes for Nike-pairs. Similarly, bottled water is used as a substitute for Coke. Numbeo does not report the price of local cigarettes or alternative apparel. The unit values are matched based on 4-digit SITC classifications that lump products together in some instances. This is especially true for apparel and carbonated beverages. We include country fixed effects in each regression and report cluster robust standard errors.

In column 1, the coefficient of the substitute is positive and highly significant. On average, the primary product is expensive wherever suitable substitutes are also expensive. Footwear unit value is of the wrong sign, but is also statistically insignificant. This is not surprising considering the fact that we are dealing with a highly differentiated product. The sign would have been more worrying had we considered the average price for a wider-range of footwear. Inland transport cost has the wrong sign, but is statistically insignificant. Again this result is not startling. The net-weight of a pair of shoes is fairly small. Therefore the cost of transportation should constitute an insignificant proportion of the retail price of footwear. Note that we are considering the cost of transporting 1 ton of goods from the port to the capital.

Long-term inflation (5 year rolling average) is positive and significant for upper and lower middle income countries, but is insignificant for low and high-income countries. We expect an increase in the deviation of inflation from its long run average to have a positive impact on consumer items that the average person purchases in low and upper middle income countries, but less so in low-income countries where prices already reflect inflation expectations by retailers. In high-income countries, such deviations are 
likely to have insignificant effect since upward price revisions might imply loss of market share. The coefficients for lower and upper middle-income countries also reflect this reasoning (the coefficient for the upper middle-income group is about a third of the value for the comparator category).

We expect the same logic to apply to exchange rate volatility. The coefficients for exchange rate variability are, however, bizarre (at least in this specification). Long-term exchange rate volatility has a negative coefficient for three of the income groups. This is highly irregular. If local demand for the items is inelastic, higher exchange rate variability should pass-through to consumer items. Conversely, if local demand is elastic, exporters of the consumer items will likely assume the loss from exchange rate fluctuation rather than risk losing their market shares. The sign should, therefore, be either positive or most likely zero (as is the case for the high-income group). The alternative specification (in differences) in column 2 corrects the signs of all coefficients except the one for upper middle-income countries. In the differenced specification, the coefficient on the substitute remains positive and highly significant. The coefficient on inland transport cost is positive and marginally significant.

In column 3, both the unit value of apparel imports and inland transportation costs are insignificant. The deviation of inflation from its long-run trend has the correct sign and is significant for three of the income groups. As discussed above, the coefficient is much higher for the low-income group possibly for two reasons. One, the prices reported for low-income countries are higher end stores, as discussed earlier. Such stores cater to the relatively affluent customers who have inelastic demand. Second, unlike in higher income countries, the range of substitutes tends to be smaller.

The same holds for exchange rate volatility. The lower income group experiences a significantly higher pass through relative to its comparators. It also suggests that exporters (or local businesses holding imported items) have higher leverage to raise prices in inflationary environments that offer a narrower range of substitutes rather than in places where inflation is moderate or low.

\section{The relationship between unexplained price variations and regulatory efficiency:}

Here we explore the potential relationship between regulatory efficiency and their impact on price distortions. We examine correlations between unexplained variations in the prices of the selected consumer items and indicators of the quality of governance (mainly using historical indices from the Global Competitiveness Report).

Table 9 provides a summary of these results. We regress the sum of the factor and error components from our fixed effect model on various indices of regulatory efficiency. We 
provide bootstrapped standard errors. The sum of the factor and error components is intended to capture such things as unobserved producer or importer margins that are not observable but are integral parts of retail pricing.

Column 1 and 2 show the relationship between unobserved variations in Nike-pair prices, goods market efficiency and the length of time it takes to process official import documents. The coefficient on time to import is distinctly positive for low income and, surprisingly, for high-income countries and nil for other income groups. Delays in time to import add to the cost of doing business, which are likely to be passed on to consumers. An efficient goods market is one in which obstacles to competition are minimal and market power is distributed across firms. Markets where the ethos of competition is central to doing business tend to have firms that have lower margins. The sign on the coefficient of goods market efficiency is negative and significant for the lower middle-income group of countries.

In column 3 and 4 , the premium to competition is shown to be greater for low-income countries than groups that are already relatively efficient markets. In other words, an increase in goods market efficiency is likely to reduce price distortions (for instance by reducing margins) by a larger amount in low-income countries than in any other group. The same holds for purging the burdensome customs procedures.

The results also show that the effects of regulatory quality are not uniform across consumer goods. They tend to be pronounced in some and comparatively marginal in others. Also, these results provide some support for results in earlier sections.

\section{Conclusion}

Inland transport and administrative costs pass-through to domestic prices as reflected in higher retail-import price differentials, especially in the sampled group. In liberalized markets, when short term interest rates go down, it becomes cheaper for firms to borrow and expand their input supply business. At the same time, with relatively low barriers to entry, newer firm also find it cheaper to join the input supply business. This could spur some competition in the input supply industry and lower mark-ups and, consequently, retail-import price differentials. In a high inflation environment, these effects are magnified. We find no impact on the retail-import price differential from exchange rate volatility. This relationship may have been masked by fairly small exchange rate volatility in the sampled countries during the study period.

Larger consumption demand reduces retail-import price gaps by either spurring competition or through government action -often the imposition of price-controls. 
Where private sector participation is extensive, large demand for fertilizer products facilitates competition among importers, marketers and distributors and lower markups and price gaps. Alternatively, government input subsidy programs in some high demand countries could place caps on retail fertilizer prices or lower them by taking control of distribution of inputs while leaving import and procurement to private actors.

After accounting for these effects, remaining country specific heterogeneity is correlated with the quality of governance and measures of goods market efficiency (the extent of competition and spread of market dominance). Even at low average income levels, marginally higher income countries have smaller retail-import price differentials may be due to relatively more regulation in retail markets in these countries.

The retail-import price differential is negatively correlated with government effectiveness. Better institutional quality both in terms of executing public policy and delivering services is, on average, likely to produce lower retail-import price gaps than a persistent history of institutional mismanagement.

Although the effect of a subsidy on retail-import price differential rests on how it is conducted, subsidies reduce the retail-import price differential in the sampled countries. Universal subsidies are likely to reduce the retail-import price gap by instituting retail price controls.

Overall, retail-import price differentials in developing countries can be understood better by examining market efficiency and the quality of the regulatory environment in addition to transportation and finance costs. Where there are stronger checks on governance and its quality, regulation enhances market efficiency and does not distort it. In such circumstances, government trade policy wields little power to skew benefits to favour some private actors over others. In these markets, whenever there is capture, it is contested and competition reduces mark-ups, and retail-import price differentials.

Delays in time to import add to the cost of doing business, which are likely to be passed on to consumers. An increase in goods market efficiency is likely to reduce price distortions substantially in low-income countries than in any other group. 


\section{References}

Baldwin, Robert E. and Christopher Magee. (2000). "Is Trade Policy for Sale? Congressional Voting on Recent Trade Bills," Public Choice 105:79-101.

Demeke, Mulat, Kelly, Valerie, Jayne, T.S, Ali Said, Le Vallee, J.C., Chen, H. (1998). "Agricultural market performance and determinants of fertilizer use in Ethiopia". Grain Market Research Project Working Paper, no. 10 / Ministry of Economic Development and Cooperation. Ethiopia.

Gopinath, Gita \& Pierre-Olivier Gourinchas \& Chang-Tai Hsieh \& Nicholas Li. (2011). "International Prices, Costs, and Mark-up Differences," American Economic Review, American Economic Association, vol. 101(6): 2450-86, October.

Frankel, Jeffrey \& David Parsley \& Shang-Jin Wei (2012). "Slow Pass-through around the World: A New Import for Developing Countries?" Open Economies Review, Springer, vol. 23(2): 213-251, April.

Hernandez, M. A. and Torero, M. (2013). Market concentration and pricing behaviour in the fertilizer industry: a global approach. Agricultural Economics, 44, pages 723-734. doi: 10.1111/agec.12084

IFDC-IFPRI (2012). Improving Fertilizer Markets in West Africa: The Fertilizer Supply Chain in Senegal. Paper Series IFDC P-43. Alabama, USA.

Johnson, M., R. Birner, J. Chamberlin, X. Diao, S. Fan, A. Nin-Pratt, D. Resnick, L. You and B. Yu. 2008. Regional Strategic Alternatives for Agriculture-Led Growth and Poverty Reduction in West Africa. ReSAKSS Working Paper 22. Washington, DC: International Food Policy Research Institute.

Knetter, M. (1994). Why are Retail Prices in Japan so High? Evidence from German Export Prices. National Bureau of Economic Research. Working paper 4894.

Morris, M. L., V. A. Kelly, R. J. Kopicki, and D. Byerlee. (2007). Fertilizer use in African agriculture: Lessons learned and good practice guidelines. Directions in Development Series, Agriculture and Rural Development. Washington, D.C. World Bank.

Stiglitz, J. and Weiss, A. (1981). Credit Rationing in Markets with Imperfect Information. American Economic Review, Vol 71, pages 393-409.

Wittman, D, 1989. Why Democracies Produce Efficient Results. Journal of Political Economy, University of Chicago Press, vol. 97(6), pages 1395-1424, December. 


\section{Appendix}

Table 3 Descriptive statistics

\begin{tabular}{|c|c|c|c|c|c|c|}
\hline Variable & & Mean & Std. Dev. & Min & Max & Observations \\
\hline \multirow[t]{3}{*}{$p_{i, t}$} & overall & 663.67 & 146.43 & 274.80 & 1136.29 & $\mathrm{~N}=168$ \\
\hline & between & & 67.84 & 534.16 & 796.30 & $\mathrm{n}=$ \\
\hline & within & & 130.93 & 404.31 & 1070.07 & $\mathrm{~T}=$ \\
\hline \multirow[t]{3}{*}{$p_{i, t}^{m}$} & overall & 380.54 & 125.67 & 120.91 & 757.15 & $\mathrm{~N}=168$ \\
\hline & between & & 50.28 & 301.34 & 467.62 & $\mathrm{n}=$ \\
\hline & within & & 115.89 & 133.96 & 764.90 & $\mathrm{~T}=$ \\
\hline \multirow[t]{3}{*}{$Y_{i, t}$} & overall & 283.13 & 81.61 & 99.04 & 537.44 & $\mathrm{~N}=168$ \\
\hline & between & & 65.66 & 209.08 & 419.88 & $n=$ \\
\hline & within & & 51.31 & 165.73 & 542.69 & $\mathrm{~T}=$ \\
\hline \multirow[t]{3}{*}{$\ln Y_{i, t}$} & overall & 5.63 & 0.26 & 5.14 & 6.29 & $\mathrm{~N}=156$ \\
\hline & between & & 0.22 & 5.34 & 6.03 & $n=$ \\
\hline & Within & & 0.14 & 5.24 & 6.09 & $\mathrm{~T}=$ \\
\hline \multirow[t]{3}{*}{$\mathrm{TP}_{i, t}$} & Overall & 126.42 & 53.55 & 45.85 & 249.50 & $\mathrm{~N}=168$ \\
\hline & between & & 54.35 & 61.90 & 224.33 & $\mathrm{n}=$ \\
\hline & within & & 10.42 & 102.09 & 154.21 & $\mathrm{~T}=$ \\
\hline \multirow[t]{3}{*}{$\mathrm{Y}_{i, t}-\mathrm{TP}_{i, t}$} & overall & 158.70 & 70.90 & 25.46 & 376.01 & $N=166$ \\
\hline & between & & 52.37 & 69.99 & 261.40 & $\mathrm{n}=$ \\
\hline & within & & 49.44 & 38.76 & 397.76 & $\mathrm{~T}$-bar $=11.85$ \\
\hline \multirow[t]{3}{*}{$\ln \left(\mathrm{Y}_{i, t}-\mathrm{TP}_{i, t}\right)$} & overall & 4.96 & 0.49 & 3.24 & 5.93 & $N=166$ \\
\hline & between & & 0.37 & 4.13 & 5.55 & $\mathrm{n}=$ \\
\hline & within & & 0.33 & 4.00 & 6.24 & T-bar $=11.85$ \\
\hline \multirow[t]{3}{*}{$\ln \left(\mathrm{TP}_{i, t}\right)$} & overall & 4.75 & 0.45 & 3.83 & 5.52 & $\mathrm{~N}=168$ \\
\hline & between & & 0.45 & 4.10 & 5.41 & $n=$ \\
\hline & within & & 0.10 & 4.47 & 5.01 & $\mathrm{~T}=12$ \\
\hline \multirow[t]{3}{*}{$\ln (\text { cons })_{i, t}$} & overall & 10.228 & 2.184 & 3.57 & 13.34 & $\mathrm{~N}=168$ \\
\hline & between & & 2.056 & 6.14 & 12.76 & $\mathrm{n}=$ \\
\hline & within & & 0.907 & 7.12 & 14.79 & $\mathrm{~T}=$ \\
\hline \multirow[t]{3}{*}{$\mathrm{r}_{i, t}$} & overall & 17.54 & 7.54 & 7.00 & 50.54 & $\mathrm{~N}=152$ \\
\hline & between & & 6.29 & 7.51 & 33.88 & $\mathrm{n}=$ \\
\hline & within & & 4.23 & 2.95 & 38.63 & $\mathrm{~T}=10.85$ \\
\hline \multirow[t]{3}{*}{$\sigma_{i, t}$} & overall & 24.02 & 36.08 & 0.03 & 244.09 & $N=168$ \\
\hline & between & & 23.82 & 0.30 & 85.78 & $\mathrm{n}=$ \\
\hline & within & & 27.78 & -59.60 & 182.33 & $\mathrm{~T}=$ \\
\hline \multirow[t]{3}{*}{$\pi \pi_{i, t}$} & overall & 7.75 & 9.37 & -19.18 & 68.22 & $\mathrm{~N}=168$ \\
\hline & between & & 5.19 & 1.14 & 21.31 & $\mathrm{n}=$ \\
\hline & within & & 7.91 & -20.84 & 54.66 & $\mathrm{~T}=$ \\
\hline \multirow[t]{3}{*}{$\mathbb{M}_{i, t}$} & overall & 3.91 & 0.37 & 2.98 & 4.81 & $\mathrm{~N}=105$ \\
\hline & between & & 0.31 & 3.21 & 4.33 & $\mathrm{n}=14$ \\
\hline & within & & 0.22 & 3.31 & 4.50 & T-bar =7.5 \\
\hline
\end{tabular}


Table 4 Determinants of price differential

\begin{tabular}{|c|c|c|c|c|}
\hline VARIABLES & $\begin{array}{c}(1) \\
\ln Y_{i, t}\end{array}$ & $\begin{array}{c}(2) \\
\ln Y_{i, t}\end{array}$ & $\begin{array}{c}(3) \\
\ln Y_{i, t}\end{array}$ & $\begin{array}{c}(4) \\
\ln Y_{i, t}\end{array}$ \\
\hline $\ln \left(\mathrm{TP}_{i, t}\right)$ & $\begin{array}{c}0.21 \\
(0.143)\end{array}$ & $\begin{array}{c}0.23^{*} \\
(0.128)\end{array}$ & $\begin{array}{l}0.28^{* *} \\
(0.128)\end{array}$ & $\begin{array}{l}0.27^{* *} \\
(0.141)\end{array}$ \\
\hline $\mathrm{r}_{i, t}$ & $\begin{array}{l}0.005^{*} \\
(0.003)\end{array}$ & $\begin{array}{l}0.005^{*} \\
(.0029)\end{array}$ & $\begin{array}{l}-0.005 \\
(0.005)\end{array}$ & $\begin{array}{l}-0.008 \\
(0.005)\end{array}$ \\
\hline $\ln (\text { cons })_{\mathrm{i}, \mathrm{t}} \times$ trend & & & & $\begin{array}{c}-0.0022^{*} \\
(0.001)\end{array}$ \\
\hline$\sigma_{i, t}$ & & & $\begin{array}{l}0.0001 \\
(0.000)\end{array}$ & $\begin{array}{l}0.0001 \\
(0.000)\end{array}$ \\
\hline$\pi_{i, t} \times \mathrm{r}_{i, t}$ & & & $\begin{array}{c}0.0001^{* *} \\
(0.000)\end{array}$ & $\begin{array}{c}0.0005^{* * *} \\
(0.000)\end{array}$ \\
\hline 2003.year & $\begin{array}{c}-0.148^{* * *} \\
(0.052)\end{array}$ & $\begin{array}{c}-0.151^{* * *} \\
(0.052)\end{array}$ & $\begin{array}{c}-0.169^{* * *} \\
(0.053)\end{array}$ & $\begin{array}{c}-0.1522^{* * *} \\
(0.054)\end{array}$ \\
\hline 2004.year & $\begin{array}{l}-0.035 \\
(0.053)\end{array}$ & $\begin{array}{l}-0.041 \\
(0.053)\end{array}$ & $\begin{array}{l}-0.065 \\
(0.054)\end{array}$ & $\begin{array}{r}-0.0307 \\
(0.057)\end{array}$ \\
\hline 2005.year & $\begin{array}{c}-0.114^{* *} \\
(0.054)\end{array}$ & $\begin{array}{c}-0.123^{* *} \\
(0.054)\end{array}$ & $\begin{array}{c}-0.153^{* * *} \\
(0.057)\end{array}$ & $\begin{array}{l}-0.1001 \\
(0.064)\end{array}$ \\
\hline 2006.year & $\begin{array}{c}-0.136^{* *} \\
(0.055)\end{array}$ & $\begin{array}{c}-0.148^{* *} \\
(0.055)\end{array}$ & $\begin{array}{c}-0.165^{* * *} \\
(0.055)\end{array}$ & $\begin{array}{l}-0.0890 \\
(0.071)\end{array}$ \\
\hline 2007.year & $\begin{array}{c}-0.213^{* * *} \\
(0.055)\end{array}$ & $\begin{array}{c}-0.228^{* * *} \\
(0.055)\end{array}$ & $\begin{array}{c}-0.249^{* * *} \\
(0.056)\end{array}$ & $\begin{array}{c}-0.1514^{*} \\
(0.080)\end{array}$ \\
\hline 2008.year & $\begin{array}{l}-0.104^{*} \\
(0.055)\end{array}$ & $\begin{array}{c}-0.124^{* *} \\
(0.055)\end{array}$ & $\begin{array}{c}-0.142^{* *} \\
(0.057)\end{array}$ & $\begin{array}{l}-0.0196 \\
(0.091)\end{array}$ \\
\hline 2009.year & $\begin{array}{l}-0.107^{*} \\
(0.057)\end{array}$ & $\begin{array}{l}-0.132^{*} \\
(0.057)\end{array}$ & $\begin{array}{c}-0.154^{* *} \\
(0.059)\end{array}$ & $\begin{array}{l}-0.0073 \\
(0.104)\end{array}$ \\
\hline 2010.year & $\begin{array}{l}-0.115^{*} \\
(0.065)\end{array}$ & $\begin{array}{c}-0.149^{* *} \\
(0.065)\end{array}$ & $\begin{array}{c}-0.165^{* *} \\
(0.067)\end{array}$ & $\begin{array}{l}-0.0013 \\
(0.117)\end{array}$ \\
\hline 2011.year & $\begin{array}{c}-0.181^{* * *} \\
(0.064)\end{array}$ & $\begin{array}{c}-0.216^{* * *} \\
(0.064)\end{array}$ & $\begin{array}{c}-0.238^{* * *} \\
(0.067)\end{array}$ & $\begin{array}{c}-0.0524 \\
(0.127)\end{array}$ \\
\hline 2012.year & $\begin{array}{l}-0.020 \\
(0.064)\end{array}$ & $\begin{array}{l}-0.059 \\
(0.064)\end{array}$ & $\begin{array}{l}-0.077 \\
(0.067)\end{array}$ & $\begin{array}{l}0.1312 \\
(0.139)\end{array}$ \\
\hline 2013.year & $\begin{array}{l}-0.007 \\
(0.066)\end{array}$ & $\begin{array}{l}-0.007 \\
(0.066)\end{array}$ & $\begin{array}{l}-0.082 \\
(0.072)\end{array}$ & $\begin{array}{l}0.1466 \\
(0.151)\end{array}$ \\
\hline Constant & $\begin{array}{c}4.653^{* * *} \\
(0.673)\end{array}$ & $\begin{array}{c}5.658^{* * *} \\
(0.135)\end{array}$ & $\begin{array}{c}4.583^{* * *} \\
(0.663)\end{array}$ & $\begin{array}{c}4.7246^{* * *} \\
(0.662)\end{array}$ \\
\hline Observations & 140 & 140 & 140 & 140 \\
\hline R-squared & 0.30 & 0.30 & 0.34 & 0.36 \\
\hline Number of id & 13 & 13 & 13 & 13 \\
\hline Country FE & Yes & Yes & Yes & Yes \\
\hline Year FE & Yes & Yes & Yes & Yes \\
\hline Instruments & No & $\log (G D P p c)$ & $\log (G D P p c)$ & $\log (G D P p c)$ \\
\hline
\end{tabular}


Table 5. Governance and market efficiency

\begin{tabular}{cccc}
\hline & $(1)$ & $(2)$ & $(3)$ \\
VARIABLES & $\mathrm{u}[\mathrm{i}]+\mathrm{e}[\mathrm{id}, \mathrm{t}]$ & $\mathrm{u}[\mathrm{i}]+\mathrm{e}[\mathrm{id}, \mathrm{t}]$ & $\mathrm{u}[\mathrm{i}]+\mathrm{e}[\mathrm{id}, \mathrm{t}]$ \\
$\ln (\mathrm{y})$ & & & \\
& $-0.276^{* * *}$ & $-0.614^{* * *}$ & $-0.484^{* * *}$ \\
$\mathbb{G}$ & $(0.0995)$ & $(0.0741)$ & $(0.0885)$ \\
& $-0.221^{* *}$ & $-0.406^{* * *}$ & $-0.341^{* * *}$ \\
$\mathbb{M}$ & $(0.0923)$ & $(0.0545)$ & $(0.0700)$ \\
& & $-0.528^{* * *}$ & $-0.332^{* * *}$ \\
$\mathbb{S}$ & & $(0.102)$ & $(0.121)$ \\
& & & $-0.140^{* * *}$ \\
Constant & & & $(0.0498)$ \\
& 0.0122 & 0.00694 & $0.0832^{* *}$ \\
& $(0.0268)$ & $(0.0219)$ & $(0.0379)$ \\
Observations & & & 81 \\
R-squared & 0.101 & 81 & 0.447 \\
SE & No & 0.394 & bootstrapped \\
Country FE & No & No & No \\
Year FE & & & 3.22 \\
Condition \# & & & 1.67 \\
Mean VIF & & &
\end{tabular}

Standard errors in

parentheses

${ }^{* * *} \mathrm{p}<0.01,{ }^{* *} \mathrm{p}<0.05,{ }^{*} \mathrm{p}<0.1$

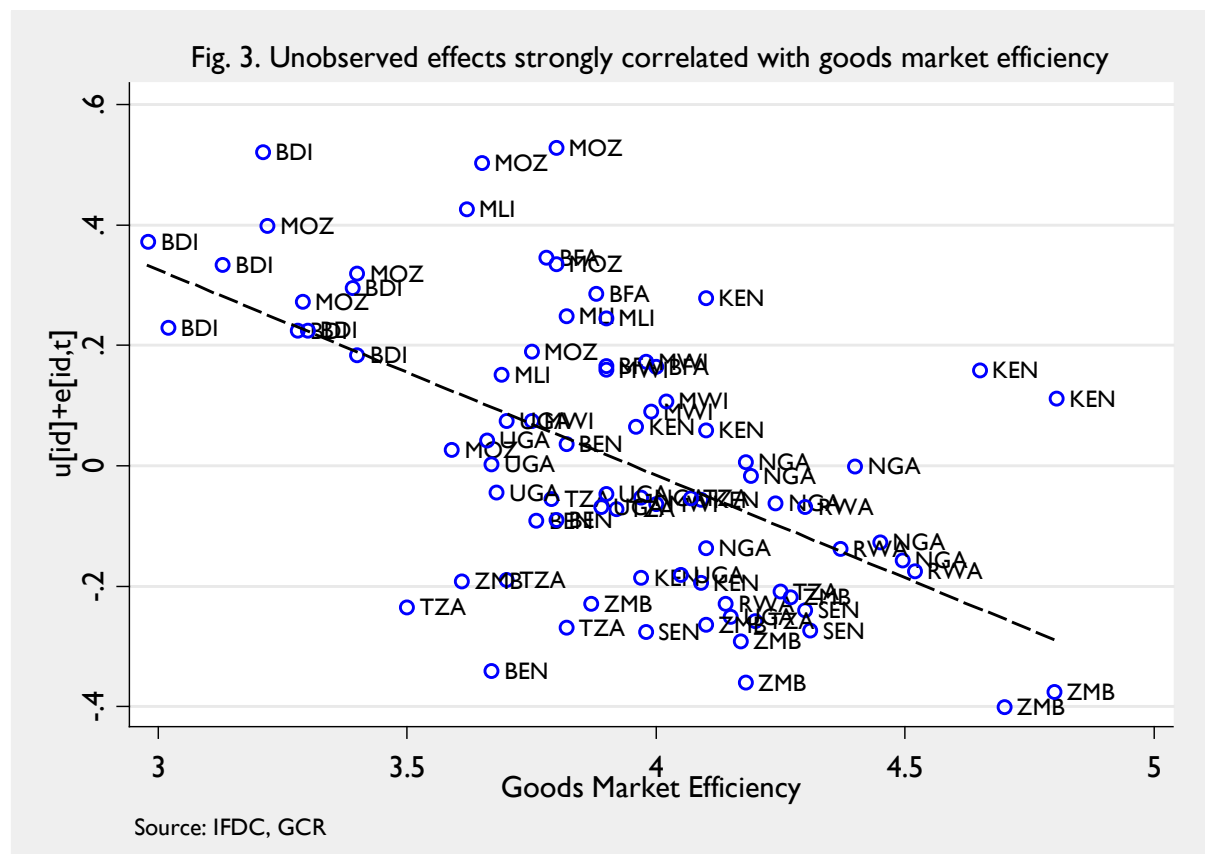


Fig 4. Average retail-import price differentials over (2002-2013)

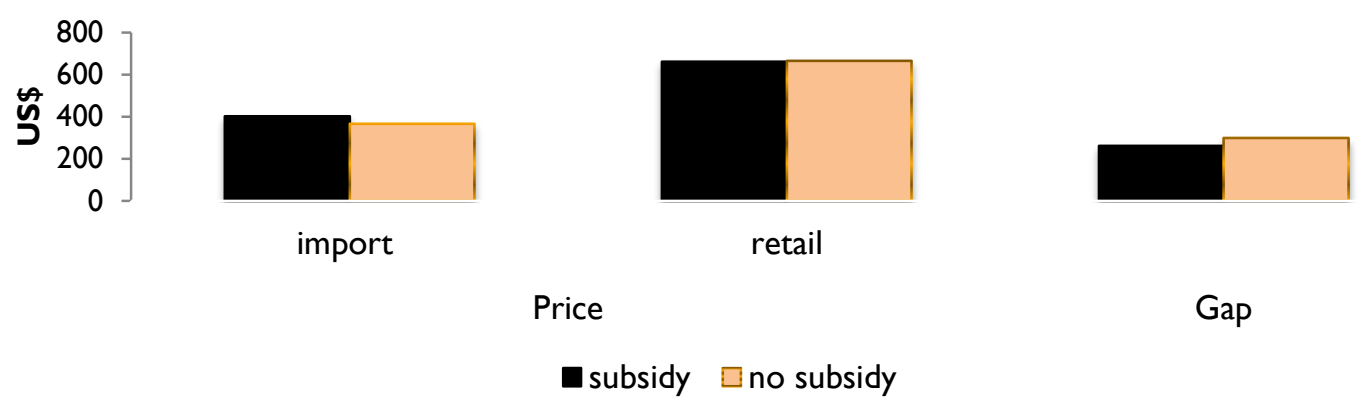

Fig. 5. Average retail-import price differentials over (2002-2013) in two subsidy regimes

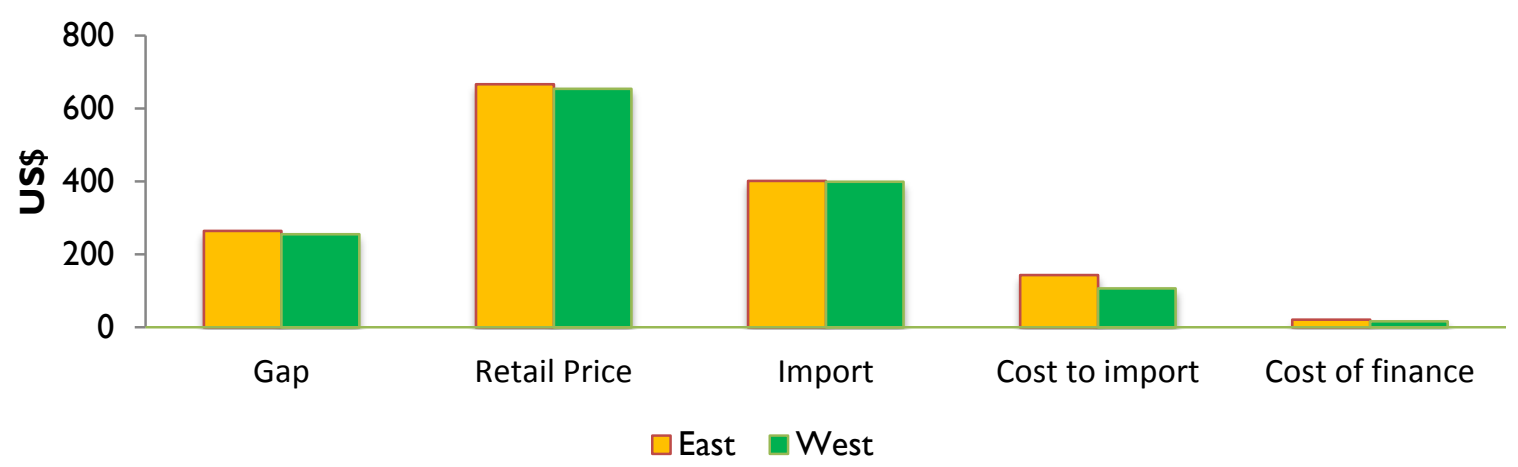


Table 6: Crowd count and ratio of per-capita income to reported salary (weight)

\begin{tabular}{|c|c|c|c|c|c|c|c|c|c|c|c|}
\hline \multicolumn{3}{|c|}{ Low income } & \multicolumn{3}{|c|}{ Lower Middle Income } & \multicolumn{3}{|c|}{ Upper Middle Income } & \multicolumn{3}{|c|}{ Non-OECD: High income } \\
\hline & Count & Weight & & Count & Weight & & Count & Weight & & Count & Weight \\
\hline Country & & Mean & Country & & Mean & Country & & Mean & Country & & Mean \\
\hline Bangladesh & 55 & 0.15 & Egypt & 144.8 & 0.94 & Albania & 33.3 & 0.64 & Bahrain & 57 & 1.28 \\
\hline Cambodia & 38 & 0.17 & Georgia & 49.7 & 0.68 & Algeria & 41 & 0.86 & Croatia & 166.8 & 1.13 \\
\hline Ethiopia & 31.7 & 0.1 & Ghana & 32 & 0.3 & Argentina & 93.6 & 0.96 & Cyprus & 75.5 & 1.04 \\
\hline Kenya & 66.3 & 0.1 & India & 1634.4 & 0.26 & Azerbaijan & 35 & 0.5 & Kuwait & 76 & 1.17 \\
\hline Nepal & 48 & 0.21 & Indonesia & 169.4 & 0.78 & Bosnia and $\mathrm{H}$. & 62.6 & 0.48 & Latvia & 66.3 & 1.56 \\
\hline \multirow[t]{2}{*}{ Tanzania } & 34 & 0.1 & Moldova & 29.5 & 0.33 & Brazil & 533 & 0.95 & Lithuania & 91 & 1.74 \\
\hline & & & Morocco & 73 & 0.52 & Colombia & 92.2 & 1.05 & Oman & 58.3 & 0.54 \\
\hline \multirow[t]{20}{*}{ Total } & 46 & 0.14 & Nigeria & 57 & 0.29 & Costa Rica & 53.8 & 0.82 & Puerto rice & 82.2 & 1.41 \\
\hline & & & Philippines & 233 & 0.5 & Dominican rep. & 63.5 & 0.9 & Qatar & 88.4 & 1.19 \\
\hline & & & Sir lank & 56.5 & 0.53 & Ecuador & 66.8 & 0.97 & Russia & 440 & 1 \\
\hline & & & Syria & 47.5 & 0.54 & Hungary & 163.4 & 1.75 & Saudi Arabia & 195 & 0.96 \\
\hline & & & Ukraine & 191.6 & 0.61 & Jordan & 62.8 & 0.47 & Singapore & 258.8 & 1.33 \\
\hline & & & Vietnam & 78.5 & 0.2 & Kazakhstan & 54.7 & 1.32 & Taiwan & 65.2 & 1.3 \\
\hline & & & & & & Lebanon & 46.2 & 0.65 & UAE & 238.4 & 0.6 \\
\hline & & & Total & 263.6 & 0.51 & Libya & 36 & 0.86 & Uruguay & 60.8 & 0.78 \\
\hline & & & & & & Macedonia & 70.5 & 0.71 & & & \\
\hline & & & & & & Malaysia & 313.6 & 0.77 & Total & 142.1 & 1.14 \\
\hline & & & & & & Panama & 36.4 & 0.72 & & & \\
\hline & & & & & & Peru & 49.5 & 0.73 & & & \\
\hline & & & & & & Romania & 311.2 & 1.26 & & & \\
\hline & & & & & & Serbia & 141.2 & 0.62 & & & \\
\hline & & & & & & South Africa & 276.2 & 0.37 & & & \\
\hline & & & & & & Thailand & 179.2 & 1.05 & & & \\
\hline & & & & & & Tunisia & 47.3 & 0.9 & & & \\
\hline & & & & & & Turkey & 319.2 & 1 & & & \\
\hline & & & & & & Venezuela & 42.8 & 0.99 & & & \\
\hline & & & & & & Total & 134.7 & 0.84 & & & \\
\hline
\end{tabular}


Table 7. Descriptive Statistics

\begin{tabular}{|ccccccc|}
\hline Low Income & \multicolumn{7}{c|}{} & & & & \\
\hline Variable & Obs & Mean & Std. Dev. & Min & Max \\
\hline Nike pair & 18 & 70.99 & 24.34 & 32.5 & 112.5 \\
Coke (0.331) & 19 & 0.57 & 0.16 & 0.32 & 0.87 \\
$\begin{array}{c}\text { Levis 501 } \\
\text { Cigarettes (Marlboro, } 1\end{array}$ & 19 & 42.71 & 14.22 & 23.5 & 70.0 \\
$\begin{array}{c}\text { pack) } \\
\text { Inland transport } \\
\text { (US\$/ton) }\end{array}$ & 19 & 1.92 & .581 & 1 & 2.95 \\
$\begin{array}{c}\text { Inflation (5yr rolling } \\
\text { average) }\end{array}$ & 19 & 2,211 & 0.45 & 3.75 & 5.37 \\
$\begin{array}{c}\text { Exchange Rate Volatility } \\
\text { log, 5yr rolling average.) }\end{array}$ & 19 & 10.04 & 5.37 & 3.57 & 23.7 \\
$\begin{array}{c}\text { Annual after-tax Salary } \\
\text { (US\$) }\end{array}$ & 19 & 4,184 & 1,667 & 1,773 & 8,354 \\
\hline
\end{tabular}

\begin{tabular}{|cccccc|}
\hline Upper Middle Income & & & & & \\
\hline Variable & Obs & Mean & Std. Dev. & Min & Max \\
\hline Nike-pair & 107 & 94.21 & 22.91 & 39.38 & 151.9 \\
Coke (0.331) & 108 & 1.08 & 0.42 & 0.43 & 2.07 \\
$\quad$ Levis 501 & 108 & 78.32 & 25.32 & 34.32 & 166.96 \\
$\begin{array}{c}\text { Cigarettes (Marlboro, 1 } \\
\text { pack) }\end{array}$ & 110 & 2.89 & 1.13 & .97 & 9.5 \\
$\begin{array}{c}\text { Inland transport } \\
\text { (US\$/ton) }\end{array}$ & 110 & 1,878 & 0.59 & 2.97 & 6.12 \\
$\begin{array}{c}\text { Inflation (5yr rolling } \\
\text { average) }\end{array}$ & 102 & 5.81 & 4.80 & -1.16 & 35.62 \\
$\begin{array}{c}\text { Exchange Rate Volatility } \\
\text { (log, 5yr rolling average.) } \\
\text { Annual after-tax Salary } \\
\text { (US\$) }\end{array}$ & 110 & -.441 & 2.723 & -7.74 & 5.19 \\
$\quad 109$ & 8,359 & 3,612 & 2,421 & 20,772 \\
\hline
\end{tabular}

\begin{tabular}{|cccccc|}
\hline Lower Middle Income & & & & & \\
\hline Variable & Obs & Mean & Std. Dev. & Min & Max \\
\hline Nike-pair & 48 & 87.36 & 26.23 & 49.39 & 150.00 \\
Coke (0.331) & 50 & 0.68 & 0.32 & 0.34 & 2.00 \\
Levis 501 & 48 & 57.43 & 22.22 & 24.50 & 114.81 \\
$\begin{array}{c}\text { Cigarettes (Marlboro, } 1 \\
\quad \begin{array}{c}\text { pack) } \\
\text { Inland transport } \\
\text { (US\$/ton) }\end{array}\end{array}$ & 49 & 1.95 & 1.03 & .725 & 5.07 \\
$\begin{array}{c}\text { Inflation (5yr rolling } \\
\text { average) }\end{array}$ & 41 & 7.68 & 3.67 & 1.10 & 17.72 \\
$\begin{array}{c}\text { Exchange Rate Volatility } \\
\text { (log, 5yr rolling average) } \\
\text { Annual after-tax Salary } \\
\text { (US\$) }\end{array}$ & 50 & 1.35 & 3.03 & -2.93 & 7.613 \\
& 50 & 4,769 & 1,637 & 2,400 & 10,062 \\
\hline
\end{tabular}

\begin{tabular}{|cccccc|}
\hline Non-OECD high income & & & & & \\
\hline Variable & Obs & Mean & Std. Dev. & Min & Max \\
\hline Nike-pair & 63 & 94.69 & 16.28 & 40.00 & 130 \\
Coke (0.331) & 64 & 1.15 & 0.59 & 0.36 & 2.49 \\
$\begin{array}{c}\text { Levis 501 } \\
\text { Cigarettes (Marlboro, } 1\end{array}$ & 61 & 86.04 & 23.52 & 32.50 & 150.00 \\
$\begin{array}{c}\text { pack) } \\
\text { Inland transport } \\
\text { (US\$/ton) }\end{array}$ & 66 & 3.96 & 2.69 & 1.32 & 17.67 \\
$\begin{array}{c}\text { Inflation (5yr rolling } \\
\text { average) }\end{array}$ & 58 & 2.61 & 2.46 & -3.95 & 8.07 \\
$\begin{array}{c}\text { Exchange Rate Volatility } \\
\text { (log, 5yr rolling average.) } \\
\text { Annual after-tax Salary } \\
\text { (US\$) }\end{array}$ & 65 & -3.475 & 3.44 & -9.07 & 1.297 \\
\hline
\end{tabular}


Table 8. The determinants of consumer prices

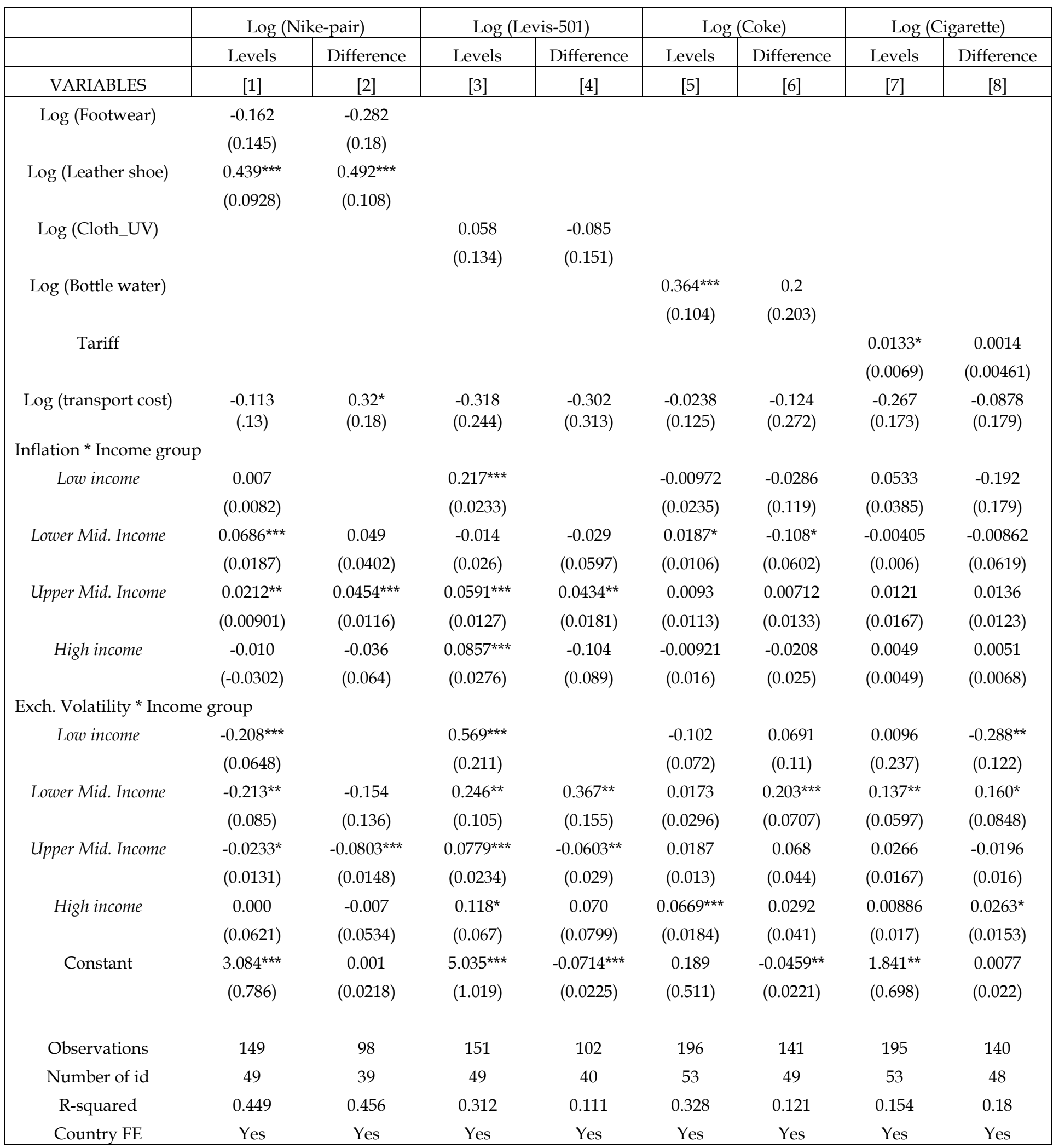


Table 9. Unexplained variation in prices vis-à-vis regulatory efficiency

\begin{tabular}{|c|c|c|c|c|c|c|c|c|}
\hline \multirow[b]{3}{*}{ VARIABLES } & \multicolumn{2}{|c|}{ Nike-pair } & \multicolumn{2}{|c|}{ Levis-501 } & \multicolumn{2}{|c|}{ Coke } & \multicolumn{2}{|c|}{ Cigarettes } \\
\hline & \multicolumn{2}{|c|}{$\mathrm{U}[\mathrm{id}]+\mathrm{e}[\mathrm{id}, \mathrm{t}]$} & \multicolumn{2}{|c|}{$\mathrm{U}[\mathrm{id}]+\mathrm{e}[\mathrm{id}, \mathrm{t}]$} & \multicolumn{2}{|c|}{$\mathrm{U}[\mathrm{id}]+\mathrm{e}[\mathrm{id}, \mathrm{t}]$} & \multicolumn{2}{|c|}{$[\mathrm{U}[\mathrm{id}]+\mathrm{e}[\mathrm{id}, \mathrm{t}]$} \\
\hline & (1) & (2) & (3) & (4) & (5) & (6) & (7) & (8) \\
\hline GME * Income Group & & & & & & & & \\
\hline Low Income & $\begin{array}{c}0.03 \\
(0.042)\end{array}$ & & & $\begin{array}{c}-1.29^{* * *} \\
(0.110)\end{array}$ & $\begin{array}{c}-0.21^{* * *} \\
(0.05)\end{array}$ & & & $\begin{array}{l}-0.039 \\
(0.037)\end{array}$ \\
\hline Lower M. Income & $-0.077^{*}$ & & & $-0.36^{* * *}$ & $-0.30^{* * *}$ & & & 0.027 \\
\hline & $(0.043)$ & & & $(0.09)$ & $(0.05)$ & & & $(0.031)$ \\
\hline Unner M Income & -0.050 & & & $-0.23^{* * *}$ & $-0.2^{* * *}$ & & & 0.031 \\
\hline & $(0.042)$ & & & $(0.08)$ & $(0.046)$ & & & $(0.029)$ \\
\hline High Income & -0.024 & & & -0.088 & $-0.098^{* *}$ & & & 0.020 \\
\hline & $(0.038)$ & & & $(0.068)$ & $(0.038)$ & & & $(0.026)$ \\
\hline TIM * Income Group & & & & & & & & \\
\hline Low Income & & $0.01^{* * *}$ & & & & & $-0.0082^{*}$ & \\
\hline & & $(0.002)$ & & & & & $(0.005)$ & \\
\hline Lower M. Income & & $\begin{array}{c}-0.0047 \\
(0.004)\end{array}$ & & & & & $\begin{array}{l}0.00014 \\
(0.0032)\end{array}$ & \\
\hline Upper M. Income & & 0.001 & & & & & $0.0019^{* *}$ & \\
\hline & & $(0.002)$ & & & & & $(0.0019)$ & \\
\hline High Income & & $\begin{array}{l}0.012^{* * *} \\
(0.0034)\end{array}$ & & & & & $\begin{array}{c}-0.001 \\
(0.0022)\end{array}$ & \\
\hline $\mathrm{BCP}$ * Income Group & & & & & & & & \\
\hline Low Income & & & $\begin{array}{c}-1.24^{* * *} \\
(0.109)\end{array}$ & & & $\begin{array}{c}-0.089^{* *} \\
(0.044)\end{array}$ & & \\
\hline Lower M. Income & & & $\begin{array}{l}-0.156 \\
(0.120)\end{array}$ & & & $\begin{array}{c}-0.19^{* * *} \\
(0.037)\end{array}$ & & \\
\hline Upper M. Income & & & $\begin{array}{l}-0.027 \\
(0.088)\end{array}$ & & & $\begin{array}{c}-0.079^{* *} \\
(0.036)\end{array}$ & & \\
\hline High Income & & & $\begin{array}{c}0.085 \\
(0.072)\end{array}$ & & & $\begin{array}{c}0.008 \\
(0.026)\end{array}$ & & \\
\hline Constant & $\begin{array}{c}0.194 \\
(0.172)\end{array}$ & $\begin{array}{l}-0.0340 \\
(0.0438)\end{array}$ & $\begin{array}{c}0.314 \\
(0.343)\end{array}$ & $\begin{array}{c}1.166^{* * *} \\
(0.316)\end{array}$ & $\begin{array}{c}0.819^{* * *} \\
(0.191)\end{array}$ & $\begin{array}{l}0.304^{* *} \\
(0.131)\end{array}$ & $\begin{array}{l}0.00411 \\
(0.0282)\end{array}$ & $\begin{array}{c}-0.0947 \\
(0.124)\end{array}$ \\
\hline Observations & 147 & 149 & 149 & 149 & 195 & 195 & 140 & 140 \\
\hline R-squared & 0.11 & 0.14 & 0.71 & 0.73 & 0.47 & 0.42 & 0.17 & 0.13 \\
\hline F (p-value) & 0 & 0 & 0 & 0 & 0 & 0 & 0.00333 & 0.163 \\
\hline r2_a & 0.0802 & 0.114 & 0.706 & 0.723 & 0.455 & 0.407 & 0.142 & 0.100 \\
\hline
\end{tabular}

Notes: GME refers to goods market efficiency measured on an increasing scale of 1-7 (best): Source Global Competitiveness Index. TIM -is the length of time it takes to process official documents necessary to import (import license, letter of credit etc.) (Source: World Ban Doing Business Surveys), BCP is burden of customs procedures (the length of time it takes to clear goods out of customs) (Source: GCI) 

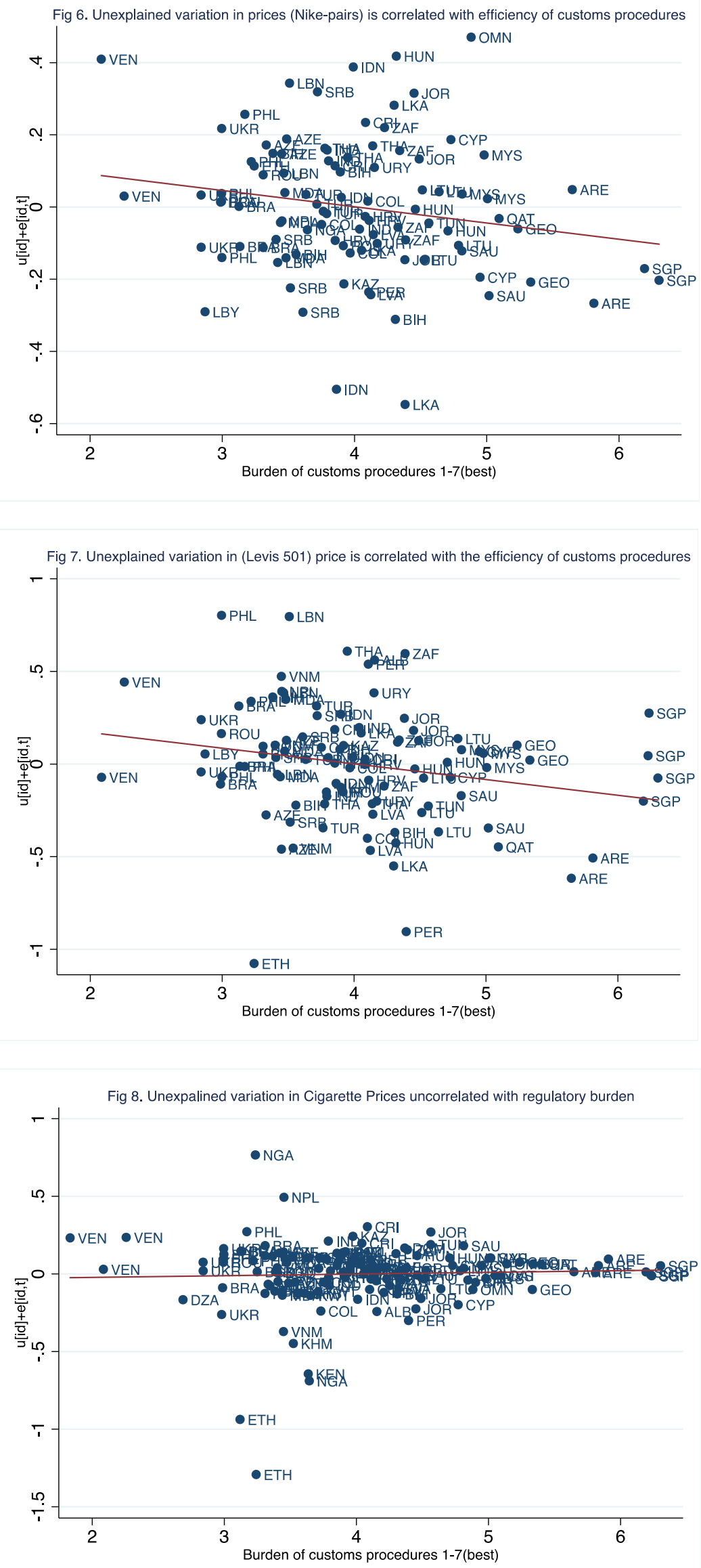